OPEN ACCESS

Edited by:

Steven Templeton,

Indiana University School of Medicine - Terre Haute,

United States

Reviewed by:

Babak Baban,

Augusta University, United States Michael K. Mansour, Massachusetts General Hospital, United States

*Correspondence: Vera Lúcia Garcia Calich v/calich@icb.usp.br

Specialty section:

This article was submitted to Microbial Immunology, a section of the journal

Frontiers in Immunology

Received: 12 August 2017 Accepted: 26 October 2017 Published: 13 November 2017

Citation:

de Araújo EF, Loures FV, Feriotti C, Costa T, Vacca C, Puccetti P, Romani L and Calich VLG (2017) Disease Tolerance Mediated by Phosphorylated Indoleamine-2,3 Dioxygenase Confers Resistance to a Primary Fungal Pathogen.

Front. Immunol. 8:1522. doi: 10.3389/fimmu.2017.01522

\section{Disease Tolerance Mediated by Phosphorylated Indoleamine-2,3 Dioxygenase Confers Resistance to a Primary Fungal Pathogen}

\author{
Eliseu Frank de Araújo', Flávio Vieira Loures', Cláudia Feriotti', Tania Costa', \\ Carmine Vacca ${ }^{2}$, Paolo Puccetti ${ }^{2}$, Luigina Romani ${ }^{2}$ and Vera Lúcia Garcia Calich ${ }^{1 *}$ \\ ${ }^{1}$ Department of Immunology, Institute of Biomedical Sciences, University of São Paulo, São Paulo, Brazil, \\ ${ }^{2}$ Department of Experimental Medicine, University of Perugia, Perugia, Italy
}

Resistance to primary fungal pathogens is usually attributed to the proinflammatory mechanisms of immunity conferred by interferon- $\gamma$ activation of phagocytes that control microbial growth, whereas susceptibility is attributed to anti-inflammatory responses that deactivate immunity. This study challenges this paradigm by demonstrating that resistance to a primary fungal pathogen such as Paracoccidiodes brasiliensis can be mediated by disease tolerance, a mechanism that preserves host fitness instead of pathogen clearance. Among the mechanisms of disease tolerance described, a crucial role has been ascribed to the enzyme indoleamine-2,3 dioxygenase (IDO) that concomitantly controls pathogen growth by limiting tryptophan availability and reduces tissue damage by decreasing the inflammatory process. Here, we demonstrated in a pulmonary model of paracoccidioidomycosis that IDO exerts a dual function depending on the resistant pattern of hosts. IDO activity is predominantly enzymatic and induced by IFN- $\gamma$ signaling in the pulmonary dendritic cells (DCs) from infected susceptible (B10.A) mice, whereas phosphorylated IDO (pIDO) triggered by TGF- $\beta$ activation of DCs functions as a signaling molecule in resistant mice. IFN- $\gamma$ signaling activates the canonical pathway of NF-кB that promotes a proinflammatory phenotype in B10.A DCs that control fungal growth but ultimately suppress T cell responses. In contrast, in AVJ DCs IDO promotes a tolerogenic phenotype that conditions a sustained synthesis of TGF- $\beta$ and expansion of regulatory $T$ cells that avoid excessive inflammation and tissue damage contributing to host fitness. Therefore, susceptibility is unexpectedly mediated by mechanisms of proinflammatory immunity that are usually associated with resistance, whereas genetic resistance is based on mechanisms of disease tolerance mediated by pIDO, a phenomenon never described in the protective immunity against primary fungal pathogens.

Keywords: paracoccidioidomycosis, indoleamine-2,3 dioxygenase, pulmonary dendritic cells, disease tolerance, phosphorylated indoleamine-2,3 dioxygenase, signaling function

\section{INTRODUCTION}

Indolamine-2,3 dioxygenase (IDO) is an intracellular enzyme of crucial importance in the tryptophan (trp) catabolism acting along the kynurenine (Kyn) pathway $(1,2)$. Although the cytokine IFN- $\gamma$ is considered the major inducer of IDO expression, TGF- $\beta$, TNF- $\alpha$, prostaglandins, and toll-like receptor ligands, among others, have also the ability of promoting the expression of the 
IDO gene (3-5). Among the cells of myeloid origin, dendritic cells (DCs) express the highest levels of IDO that is, however, also present in macrophages, neutrophils, endothelial cells, and fibroblasts (6-8).

Indolamine-2,3 dioxygenase was primarily associated with host defense against pathogens due to trp starvation caused by its enzymatic activity (9-11). However, the recent recognition of the immunoregulatory function of IDO and Kyn, put IDO to another level of knowledge and relevance $(11,12)$. Indeed, IDO has been recently described as an intracellular signaling molecule involved in the sustained tolerogenic activity of DCs. This signaling function is mediated by TGF- $\beta$ signaling that promotes IDO phosphorylation that ultimately activates the non-canonical NF- $\kappa \mathrm{B}$ pathway that triggers genes encoding IDO, TGF- $\beta$, IFN$\alpha$, and IFN- $\beta$, that maintain the tolerogenic activity of murine plasmacytoid DCs (12). This likely accounts for the ability of IDO to favor microbial persistence and concomitant control of inflammation during chronic infections (13-15). Therefore, acting via trp depletion and Kyn production, IDO can inhibit the proliferation of $\mathrm{T}$ cells and induce their apoptosis. Furthermore, through the aryl hydrocarbon receptor (AhR), IDO directs the conversion of naive $\mathrm{CD}^{+} \mathrm{T}$ cells into regulatory Foxp $3^{+} \mathrm{T}$ cells (Tregs) $(13,16,17)$.

Paracoccidioidomycosis (PCM), is a granulomatous disease caused by two species of the dimorphic fungus Paracoccidioides, P. brasilienis, and P. lutzii (18). Immunoprotection to PCM is mediated by prevalent Th1/Th17 immunity, whereas Th2 and Th9 responses are associated with severe forms of the disease (19-21). In a murine model of pulmonary infection, $\mathrm{A} / \mathrm{J}$ and B10.A mice were described, respectively, as resistant and susceptible to PCM. The A/J mouse strain develops a chronic and regressive PCM restricted to the lungs. Its adaptive immunity is mainly mediated by Th1 and Th17 cells that are tightly controlled by elevated numbers and activity of Treg cells. In contrast, B10.A mice develop a progressive disseminated disease associated with large amounts of fungi in non-organized lesions that mimic the severe forms of PCM (22-27).

The immunoregulatory mechanisms that control resistance to PCM are complex and not yet completely solved. In this aspect, our previous studies have shown that in pulmonary PCM, IDO is an important immunoregulatory enzyme that promotes fungal clearance and inhibits $\mathrm{T}$ cell immunity but only in susceptible mice IDO inhibition by 1-methyl-DL-tryptophan (1MT) caused progressive tissue pathology and increased mortality rates (28). This difference appeared to be mediated by the opposite innate immunity of resistant and susceptible mice. Indeed, in B10.A mice the innate immunity is preferentially proinflammatory with elevated production of IL-12 and IFN- $\gamma$, whereas in A/J mice the predominant TGF- $\beta$ secretion provides an anti-inflammatory innate response (26-30). These findings led us to hypothesize that IDO has distinct immunoregulatory roles in pulmonary PCM. Here, we could demonstrate that in susceptible mice IDO activity is IFN- $\boldsymbol{\gamma}$-dependent and mediated by its catalytic activity, whereas in resistant mice a prevalent TGF- $\beta$ signaling triggered IDO phosphorylation imparting a signaling and tolerogenic function. The TGF- $\beta$-IDO-Treg interplay generates an early pathogen tolerance that allows $\mathrm{A} / \mathrm{J}$ mice to interact with a primary fungal pathogen as a commensal microbe. Thus, the signaling function of pIDO may lead to an unusual fungus-host interaction that efficiently balances tolerance and resistance mechanisms to the benefit both the pathogen and the host.

\section{MATERIALS AND METHODS}

\section{Mice}

Susceptible (B10.A) and resistant (A/J) mouse strains to Paracoccidiodes brasiliensis infection were obtained from our Isogenic Unit (Immunology Department of Institute of Biomedical Sciences of University of São Paulo, Brazil) and used at 8-11 weeks of age. Specific pathogen free mice were fed with sterilized laboratory chow and water ad libitum.

\section{Fungus}

Paracoccidiodes brasiliensis 18 ( $\mathrm{Pb} 18$ ) was used throughout this investigation. To ensure the maintenance of its virulence, the isolate was used after three serial animal passages. Pb18 yeast cells were maintained by weekly sub cultivation in semisolid Fava Netto culture medium at $37^{\circ} \mathrm{C}$ and used on the seventh day of culture. Phosphate-buffered saline (PBS)-washed yeast cells were adjusted to $20 \times 10^{6}$ cells $/ \mathrm{mL}$ based on hemocytometer counts. Viability was determined with Janus Green B vital dye (Merck) and was always higher than $85 \%$.

\section{MT Treatment and In Vivo Fungal Infection}

Mice were anesthetized and submitted to intratracheal (i.t.) $P$. brasiliensis infection as previously described. Briefly, after intraperitoneal (i.p.) anesthesia the animals were infected with $1 \times 10^{6} \mathrm{~Pb} 18$ yeast cells, contained in $50 \mu \mathrm{L}$ of PBS, by surgical i.t. inoculation, which allowed dispensing of the fungal cells directly into the lungs. The skins of the animals were then sutured, and the mice were allowed to recover under a heat lamp. Groups of infected B10.A and A/J mice were treated with daily i.p. injections of $5 \mathrm{mg} / \mathrm{mL}$ of $1 \mathrm{MT}$ or $1 \mathrm{mg} / \mathrm{mL}$ of rice starch (Sigma-Aldrich) as control. Mice were sacrificed after $96 \mathrm{~h}$ or 2 weeks of infection.

\section{Isolation of Pulmonary CD11c ${ }^{+}$Cells}

Cell suspensions of the lungs were prepared as previously described (31). The lungs were removed and digested for $60 \mathrm{~min}$ in RPMI-1640 medium (Sigma) containing collagenase $(2 \mathrm{mg} / \mathrm{mL}$ ) and DNAse $(30 \mathrm{mg} / \mathrm{mL})$. The erythrocytes were lysed with lysis buffer (TRIS + ammonium chloride) and viability determined by the trypan blue exclusion test with viabilities at least to $95 \%$. $\mathrm{CD}_{11 \mathrm{c}^{+}}$cells were isolated from total pulmonary cells by magnetic microbeads (Miltenyi Biotec, Cologne, Germany). Pellets of pulmonary cells were counted, washed and the pellet resuspended in $400 \mu \mathrm{L}$ of buffer (PBS $+0.5 \%$ BSA +2 mM EDTA). The Trypan Blue dye exclusion test was used to determine the number of viable cells present in the DCs cell suspension with viabilities at least to $95 \%$. Then, $100 \mu \mathrm{L}$ of anti-CD11c coated microspheres were added for each $10^{8}$ cells and incubated for $15 \mathrm{~min}$ at $2-8^{\circ} \mathrm{C}$. The cells were washed, the supernatant removed and the pellet resuspended in $500 \mu \mathrm{L}$ of buffer. This suspension 
was fractionated using a magnetic separation column, and purified CD $11 \mathrm{c}^{+}$DCs obtained. This fractionation methods resulted

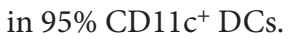

\section{Culture of DCs}

The viability of the CD $11 \mathrm{c}^{+}$cells was evaluated by the trypan blue exclusion test, and was always higher than $85 \%$. The cell suspensions were then centrifuged at $1,200 \mathrm{rpm}$ at $4^{\circ} \mathrm{C}$ for $10 \mathrm{~min}$ and resuspended in $1.0 \mathrm{~mL}$ of culture medium (RPMI-1640 medium) supplemented with $10 \%$ fetal bovine serum. The cells were adjusted to $1 \times 10^{6} / \mathrm{mL}$ and $500 \mu \mathrm{L}$ were dispensed into each well of 24 -well culture plates. The cultures were incubated at $37^{\circ} \mathrm{C}$ in an incubator containing $5 \% \mathrm{CO}_{2}-95 \%$ air for $24 \mathrm{~h}$. After this period, the cells were removed and used in different assays.

\section{CFU Assay}

After $24 \mathrm{~h}$ of culture, DCs suspensions were lysed and $100 \mu \mathrm{L}$ of pellets plated onto $\mathrm{BHI}$-agar medium containing $5 \%$ "fungus growth factor" and $4 \%$ horse serum (32). The plates were incubated at $35^{\circ} \mathrm{C}$ and colonies counted daily until no increase in CFU was observed. The numbers $(\log 10)$ of viable $P$. brasiliensis colonies are expressed as the mean \pm SE. Two to three experiments were performed separately.

\section{NO and Cytokines Measurement}

Supernatants from DC cultures and lymphoproliferation assays were separated and stored at $-70^{\circ} \mathrm{C}$. The levels of IL-12, IL- $1 \beta$, TGF- $\beta$, IL- 6 , IFN- $\gamma$, and IL-12 were measured by a capture enzyme-linked immunosorbent assay (ELISA) with antibody pairs purchased from eBioscience. The ELISA procedure was performed according to the manufacturer's protocol, and absorbance was measured with a Versa Max Microplate Reader (Molecular Devices). The concentrations of cytokines were determined based on a standard curve of serial twofold dilutions of murine recombinant cytokines. Nitric oxide production was quantified by the accumulation of nitrite in the supernatants from in vitro protocols by a standard Griess reaction (33). All determinations were performed in duplicate, and results were expressed as micromolar concentration of NO.

\section{Determination of IDO Enzymatic Activity}

To monitor IDO enzymatic activity, Kyn were measured using a modified spectrophotometric assay (5). The amount of $50 \mu \mathrm{L}$ of $30 \%$ trichloroacetic acid was added to $100 \mu \mathrm{L}$ of DCs supernatants, vortexed, and centrifuged at $800 \mathrm{~g}$ for $5 \mathrm{~min}$. A volume of $75 \mu \mathrm{L}$ of the supernatant was then added to an equal volume of Ehrlich reagent (100 mg P-dimethylbenzaldehyde, $5 \mathrm{~mL}$ glacial acetic acid) in a 96-well microtiter plate. Optical density was measured at $492 \mathrm{~nm}$, using a Multiskan MS (Labsystems) microplate reader. A standard curve of defined L-Kyn concentrations (0-100 mM) was used to determine unknown Kyn concentrations.

\section{Flow Cytometry}

Pulmonary CD $11 \mathrm{c}^{+}$cells were obtained from $1 \mathrm{MT}$ treated and untreated B10.A and A/J mice $96 \mathrm{~h}$ and 2 weeks after $P$. brasiliensis infection. For cell surface staining, pulmonary CD11 $\mathrm{c}^{+}$cells were washed and resuspended at a concentration of $1 \times 10^{6}$ cells $/ \mathrm{mL}$ in staining buffer (PBS $1 \times, 2 \% \mathrm{FBS}, 0.5 \% \mathrm{NaN}_{3}$ ). Fc receptors were blocked by the addition of unlabeled anti-CD16/32 (Fc block; BD Biosciences). The DCs cells were then stained for $30 \mathrm{~min}$ at $4^{\circ} \mathrm{C}$ with the optimal dilution of each labeled antibody [phycoerythrin tandem Cy7 (PE-Cy7)-labeled anti-CD11c, phycoerythrin tandem Cy5 (PE-Cy5)-labeled anti-B220, pacific blue (PB)-labeled anti-CD8, phycoerythrin (PE)-labeled antiCD86, allophycocyanin (APC)-labeled anti-CD40, fluorescein isothiocyanate (FITC)-labeled MHCII (IA ${ }^{\mathrm{K}}$ ), and allophycocyanin tandem Cy7 (APC-Cy7)-labeled anti-CD11b] monoclonal antibodies (mAbs) from BD Biociences. Cells were washed twice with staining buffer, fixed with $2 \%$ paraformaldehyde (Sigma), and acquired using a FACSCanto II equipment and FACSDiva ${ }^{\circledR}$ software (BD Biosciences) and analyzed by the FlowJo software (Tree-Star, Ashland, OR, USA).

\section{Lymphocyte Proliferation Assay and Lymphocyte Phenotyping}

Spleen lymphocytes from normal B10.A and A/J mice were resuspended $\left(1 \times 10^{7}\right)$ in $1 \mathrm{~mL}$ PBS-BSA $(0.1 \%)$ and $1 \mu \mathrm{L}$ of carboxyfluorescein diacetate, succinimidly ester (CFSE) at a concentration of $5 \mathrm{mM}$ (Molecular Probes, USA). The cells were incubated at room temperature in the dark for 15 min (shaking the tube constantly). The cells were washed two times with $10 \mathrm{~mL}$ of supplemented RPMI, counted and resuspended at a concentration of $1 \times 10^{6} / \mathrm{mL}$. In parallel, purified DCs from A/J and B10.A of uninfected and infected mice, treated and untreated with 1MT were centrifuged and adjusted to $1 \times 10^{6} / \mathrm{mL}$ in supplemented medium. Aliquots of $100 \mu \mathrm{L}$ of DCs were placed in a 96-well plate (U-bottom) in the presence of lymphocytes previously stained with CFSE at a ratio $1: 10(100 \mu \mathrm{L}$ of DCs $+100 \mu \mathrm{L}$ of lymphocytes). CFSE stained lymphocytes (treated or not with 1MT), purified DCs and Concanavalin A (Sigma) stimulated lymphocytes were used as controls. The cells were incubated at $37^{\circ} \mathrm{C}$ in $5 \% \mathrm{CO}_{2}$ for 3 days. After the incubation period the cells were washed and resuspended at a concentration of $1 \times 10^{6}$ cells $/ \mathrm{mL}$ in staining buffer (PBS $1 \times, 2 \% \mathrm{FBS}, 0.5 \% \mathrm{NaN}_{3}$ ). Fc receptors were blocked by the addition of unlabeled anti-CD16/32 (Fc block; BD Biosciences). The leukocytes were then stained for $30 \mathrm{~min}$ at $4^{\circ} \mathrm{C}$ with the optimal dilution of each antibody labeled with the adequate fluorochrome (BD Biosciences). PE-labeled anti-CD44, PE-Cy7-labeled anti-CD8, and PerCP Cy5.5-labeled anti-CD4, and APC-Cy7-labeled anti-CD62L mAbs from BD Biosciences were used. Cells were washed twice with staining buffer, resuspended in $100 \mu \mathrm{L}$, and an equal volume of $2 \%$ paraformaldehyde was added to fix the cells. A minimum of 50,000 events was acquired on a FACSCanto II flow cytometer using FACSDiva $^{\circledR}$ and FlowJo softwares. Lymphocytes were identified on forward-scatter (FSC) and side-scatter (SSC) analysis. Gated cells were measured for $\mathrm{CD}^{+}$and $\mathrm{CD} 8^{+}$expression followed by CD44 expression, and cells expressing high and low levels of this molecule were gated. Gated CD44 $4^{\text {high }}$ cells were then measured for expression of low levels of CD62L identifying the effector/ memory $\mathrm{CD}^{+} \mathrm{CD} 44^{\text {high }} \mathrm{CD} 62 \mathrm{~L}^{\text {low }}$ and $\mathrm{CD} 8^{+} \mathrm{CD} 44^{\text {high }} \mathrm{CD} 62 \mathrm{~L}^{\text {low }}$ subpopulations. Gated CD $44^{\text {low }}$ cells were then measured for the expression of high levels of CD62L identifying the naive 
$\mathrm{CD} 4{ }^{+} \mathrm{CD} 44^{\text {low }} \mathrm{CD} 62 \mathrm{~L}^{\text {high }}$ and $\mathrm{CD} 8^{+} \mathrm{CD} 44^{\text {low }} \mathrm{CD} 62 \mathrm{~L}^{\text {high }}$ subpopulations (Figure S2A,B in Supplementary Material). Fifty thousand cells were acquired and the data expressed as the frequency of positive cells. The cell division index was calculated and was based on the number of $\mathrm{CFSE}^{+} \mathrm{CD}^{+}$or $\mathrm{CFSE}^{+} \mathrm{CD}^{+} \mathrm{T}$ cells found in the stimulated culture/number of $\mathrm{CFSE}^{+} \mathrm{CD} 4^{+}$or $\mathrm{CFSE}^{+} \mathrm{CD} 8^{+} \mathrm{T}$ cells in the unstimulated culture (34).

\section{Assay to Determine Regulatory $\mathrm{CD4}^{+}{ }^{+} \mathrm{CD}^{2} 5^{+} \mathrm{FoxP}^{+} \mathrm{T}$ Cells}

Culture supernatants from lymphoproliferation assays were removed and stored at $70^{\circ} \mathrm{C}$ for the determination of cytokines according to the manufacturer's protocol. The pellet cells were stained with PE-Cy7-labeled anti-CD4 and PerCP Cy5.5-labeled anti-CD25 for $30 \min 4^{\circ} \mathrm{C}$. Next, the cells were washed with staining buffer containing $2 \%$ fetal bovine serum, $0.1 \%$ azide, $100 \mu \mathrm{L}$ of PBS. The permeabilization of the plasma membrane was made with the addition of $200 \mu \mathrm{L} /$ well of Cytofix/Cytoperm (Fixation/ permeabilization kit BD Biosciences ${ }^{\circledR}$ ) at room temperature for $30 \mathrm{~min}$, protected from light. After washing the cells, the nuclear membrane permeabilization was performed using $130 \mu \mathrm{L} /$ well of solution containing $750 \mu \mathrm{L}$ of $1 \times \mathrm{PBS}, 250 \mu \mathrm{L}$ of $4 \%$ paraformaldehyde, $5 \mu \mathrm{L}$ Tween 20 Sigma $^{\circledR}$ and the cells then were incubated for $30 \mathrm{~min}$ at room temperature in the dark.

After washing the cells with cold PBS (1X), the nuclear transcription factor FoxP3 was stained with an anti-FoxP3 labeled specific antibody (APC-labeled anti-FoxP3) diluted 1/100 in staining buffer. The cells were incubated for $30 \mathrm{~min}$ at $4^{\circ} \mathrm{C}$, then washed with ice-cold PBS, fixed with $2 \%$ paraformaldehyde and stored at $4^{\circ} \mathrm{C}$ in the dark until analyzed by flow cytometry. Gates for total lymphocytes, $\mathrm{CD} 4^{+}, \mathrm{CD}^{+}{ }^{+} \mathrm{CD} 25^{+}$, and finally for $\mathrm{TCD} 4^{+} \mathrm{CD} 25^{+} \mathrm{FoxP}^{+} \mathrm{T}$ lymphocytes were made (Figure S2C in Supplementary Material). Cells were analyzed as above described.

\section{Intracellular Cytokines Measurement}

Dendritic cells obtained from the lungs were adjusted to $1 \times 10^{6}$ cells and stimulated for $6 \mathrm{~h}$ in complete medium in the presence of $100 \mathrm{ng} / \mathrm{mL}$ phorbol 12 -myristate 13 -acetate, $500 \mathrm{ng} / \mathrm{mL}$ ionomycin (both from Sigma-Aldrich; Germany), and monensin ( $3 \mathrm{mM}$, eBioscience). Cells were subsequently labeled for surface molecules (PerCP-labeled anti-CD11c) and then treated according to the manufacturer's protocol for intracellular staining using the Cytofix/Cytoperm kit (BD Biosciences). Cells were then stained with Alexa Fluor 488-labeled anti-IDO, PB-labeled anti-IL-10, PE-Cy7-labeled anti-TNF- $\alpha$, APC-CY7-labeled antiIL-12, and PE-labeled anti-TGF- $\beta$. Cells were washed twice with staining buffer, resuspended in $100 \mu \mathrm{L}$, and fixed with an equal volume of $2 \%$ paraformaldehyde. The flow cytometry data were acquired and analyzed as above described.

\section{Quantitative Analysis of mRNA Expression}

RNA was extracted from DC cultures and the RNA concentrations were determined by spectrophotometer readings at an absorbance of $260 \mathrm{~nm}$. First-strand cDNAs were synthesized from $2 \mu \mathrm{g}$ RNA using the High Capacity RNA-to-cDNA kit (Applied Biosystems) according to the manufacturer's instructions. Gene expression for the genes of IDO, IFN- $\gamma$, janus kinase 1 (JAK1), signal transducer and activator of transcription (STAT1), IL-6, suppressor of cytokine signaling 3 (SOCS3), nitric oxide synthase (NOS2), TGF- $\beta$, small mothers against decapentaplegic 2 and 3 (SMAD2 and SMAD3), inositol polyphosphate phosphatase (SHIP), Shp1, Sh22 (tyrosine phosphatases 1 and 2), IFN- $\alpha$, IFN- $\beta$, and the endogenous gene glyceraldehyde 3phosphate dehydrogenase (GAPDH) was characterized by the real time polymerase chain reaction technique (qPCR) (Applied Biosystems, Foster City, CA, USA). The samples were placed in microcentrifuge tubes for specific qPCR testing of samples containing $2 \mu \mathrm{L} \mathrm{cDNA}+10 \mu \mathrm{L}$ TaqMan PCR Master Mix (Applied Biosystems, Foster City, CA, USA) according to the following thermal profile: denaturation at $95^{\circ} \mathrm{C}$ for $15 \mathrm{~s}$, annealing at $60^{\circ} \mathrm{C}$ for $15 \mathrm{~s}$, and extension at $72^{\circ} \mathrm{C}$ for $15 \mathrm{~s}$. The sequences of the primers for Indo (Mm00492506_m1), IFN- $\gamma$ (Mm01168134_m1), Jak1 (Mm00600614_m1), Stat1 (Mm00439531_m1), IL-6 (Mm00446190_m1), SOCS3 (Mm00545913_s1), NOS2 (Mm00440502_m1), TGF- $\beta 1$ (Mm01178820_m1), Smad2 (Mm00487530_m1), Smad3 (Mm01170760_m1), Inpp5d (Ship-Mm00494987_m1), Nr0b2 (Shp1-Mm00442278_m1), PTPN11 (Shp2-Mm00448434_m1), Ifnal (Mm03030145_gH), Ifnb1 (Mm00439552_s1), and the gene endogenous transcripts in all cell types, GAPDH (Mm99999915_g1) were obtained from Applied Biosystems ready for testing. Probes were labeled with 6-carboxyfluorescein (FAM) at their $5^{\prime}$-terminal end. Data were normalized to GAPDH gene expression. TaqMan PCR assays were performed on a Stratagene MxP3005P QPCR System and data were developed using the MxPro QPCR software (Agilent Technologies, USA).

\section{NF-кB DNA-Binding ELISA-Based Assay}

Nuclear extracts from DCs were obtained using the Nuclear Extract Kit (Active Motif, USA). DNA binding activity of NF- $\kappa B$ was measured by an ELISA-based assay using a TransAM NF- $\kappa B$ kit (Active Motif, USA) following manufacturer's instructions. This assay detects binding of p65, p50, p52, and Rel-B proteins to oligonucleotides containing an NF- $\mathrm{KB}$ consensus-binding site immobilized onto 96-well plates by specific primary antibodies that recognize an epitope that is accessible only when NF- $\mathrm{KB}$ is activated and bound to its target DNA. The binding activity was quantified by spectrophotometry, the OD at $450 \mathrm{~nm}$.

\section{Western Blot Analysis}

Dendritic cells were lysed in ice-cold NP40 buffer [1\% NP40, $50 \mathrm{mmol} / \mathrm{L}$ Tris- $\mathrm{HCl}$ (pH 7.4), $150 \mathrm{mmol} / \mathrm{L} \mathrm{NaCl}, 5 \mathrm{mmol} / \mathrm{L}$ EDTA containing $5 \mathrm{mmol} / \mathrm{L} \mathrm{NaF}, 2 \mathrm{mmol} / \mathrm{L} \mathrm{Na}_{3} \mathrm{VO}_{4}, 1 \mathrm{mmol} / \mathrm{L}$ phenylmethylsulfonyl fluoride, $5 \mu \mathrm{g} / \mathrm{mL}$ leupeptine, and $5 \mu \mathrm{g} / \mathrm{mL}$ aprotinine], supplemented with a protease inhibitor (Sigma Aldrich). After incubating for $30 \mathrm{~min}$ at $4^{\circ} \mathrm{C}$, the samples were centrifuged, and the supernatants were kept as the NP40-soluble fraction. The pellets were resuspended in SDS buffer [2\% SDS, $80 \mathrm{mmol} / \mathrm{L}$ Tris (pH 6.8), $100 \mathrm{mmol} / \mathrm{L}$ DTT, and $10 \%$ glycerol]. Protein concentration was determined using a BCA assay (Pierce), and 40-60 $\mu \mathrm{g}$ of protein was run on a polyacrylamide gel and transferred to a $0.45 \mu \mathrm{m}$ nitrocellulose membrane 
(Millipore, Bedford, MA, USA). Western blotting was carried out according to a standard procedure using horseradish peroxidase-conjugated secondary antibodies (Thermo Scientific and Sigma Aldrich). mAbs used were as follows: Jak1 (1:500; Sigma-Aldrich), Stat1 (1:500; Sigma-Aldrich), IKK- $\beta$ (1:1,500; Sigma-Aldrich), IDO1 (1:200; Santa Cruz Biotechnology), Smad2 (1:2,500; Sigma-Aldrich), Ship (1:2,000; Sigma-Aldrich), Shp-2 (1:1,500; Sigma-Aldrich), and IKK- $\alpha$ (1:500; SigmaAldrich). Mouse monoclonal antimouse $\beta$-tubulin antibody (1:2,000; Sigma-Aldrich) was used as an internal control. The immunoreactive proteins were visualized with ECL plus reagents (ECL Western blotting Detection Reagents; Amersham) and enhanced chemiluminescence apparatus (ImageQuant LAS 4000). Densitometry was performed using ImageQuant TL 8.1 software.

\section{Detection of Phosphorylated IDO1 (pID01) by Western Blotting}

Lung extracts from susceptible and resistant mice infected with P. brasiliensis, treated or not with $1 \mathrm{MT}$ were obtained after $96 \mathrm{~h}$ and 2 weeks of infection and analyzed by Western Blot for detection of pIDO1. Protein concentration was determined using a BCA assay (Pierce), and $20 \mu \mathrm{g}$ of protein in Ripa Buffer and Sample buffer $4 \times$ were heated at $100^{\circ} \mathrm{C}$ for $4 \mathrm{~min}$, then on ice for $2 \mathrm{~min}$ and loaded $60 \mu \mathrm{L}$ per well in $10 \%$ SDS PAGE, $1.5 \mathrm{~mm}$. Electrophoresis was then performed by transferring the gel to the nitrocellulose membrane with the membranes incubated in blocking solution [5\% non-fat dry milk, 0.1\% Tween 20 in Tris buffer saline (TBS) for $1 \mathrm{~h}$ at room temperature on an orbital shaker]. After two washings steps with TBS-Tween $200.1 \%$ buffer, the membrane was incubated overnight with polyclonal rabbit antimouse pIDO (CV223 AP8), $2 \mu \mathrm{g} / \mathrm{mL}$ in 5\% non-fat dry milk, TBS at $0.1 \%$. The membrane was washed three times for 5 min and incubated with HRP-labeled secondary antibody (anti-rabbit HRP-Pierce) for $1 \mathrm{~h}$ at room temperature. The revelation was performed using the ECL chemiluminescent substrate for enzymatic activity detection of peroxidase (HRP) on photographic film. The same method was used with a monoclonal rabbit anti-mouse IDO1 (CV152) and monoclonal antimouse $\beta$-tubulin antibody $(1: 1,000)$.

\section{Statistical Analysis}

Data are expressed as the mean \pm SEM. Differences between groups were analyzed by analysis of variance followed by the Bonferroni test. Differences between survival times were determined with the LogRank test. Data were analyzed using GraphPad Prism 6.2 software for Windows (GraphPad). A $p$ value of $\leq 0.05$ was considered statistically significant.

\section{RESULTS}

\section{IDO Inhibition Increases the Fungal Loads of DCs from Susceptible and Resistant Mice and Down Regulates NO, Kyn, and IDO mRNA Production}

Initially, we sought to investigate the effects of IDO inhibition on the interaction of DCs, from susceptible and resistant mice, with
P. brasiliensis. To explore the effect of IDO inhibition in vivo, A/J and B10.A mice were treated or not with $1 \mathrm{MT}$ and subsequently subjected to i.t. infection with P. brasiliensis yeasts cells. Pulmonary DCs from both mouse strains were isolated $96 \mathrm{~h}$ and 2 weeks after infection and in vitro cultivated for $24 \mathrm{~h}$. Using a CFU assay it was verified that in both postinfection periods 1MT-treated DCs presented increased fungal loads than untreated cells (Figures 1A,B). The levels of NO and Kyn in the supernatants of 1MT-treated DCs from both mouse strains was significantly lower than those detected in untreated groups (Figures 1A,B). In agreement with the reduced levels of Kyn observed, a reduced expression of IDO mRNA was found in 1MT-treated groups of both mouse strains (Figures 1A,B). The reduced IDO mRNA expression was further

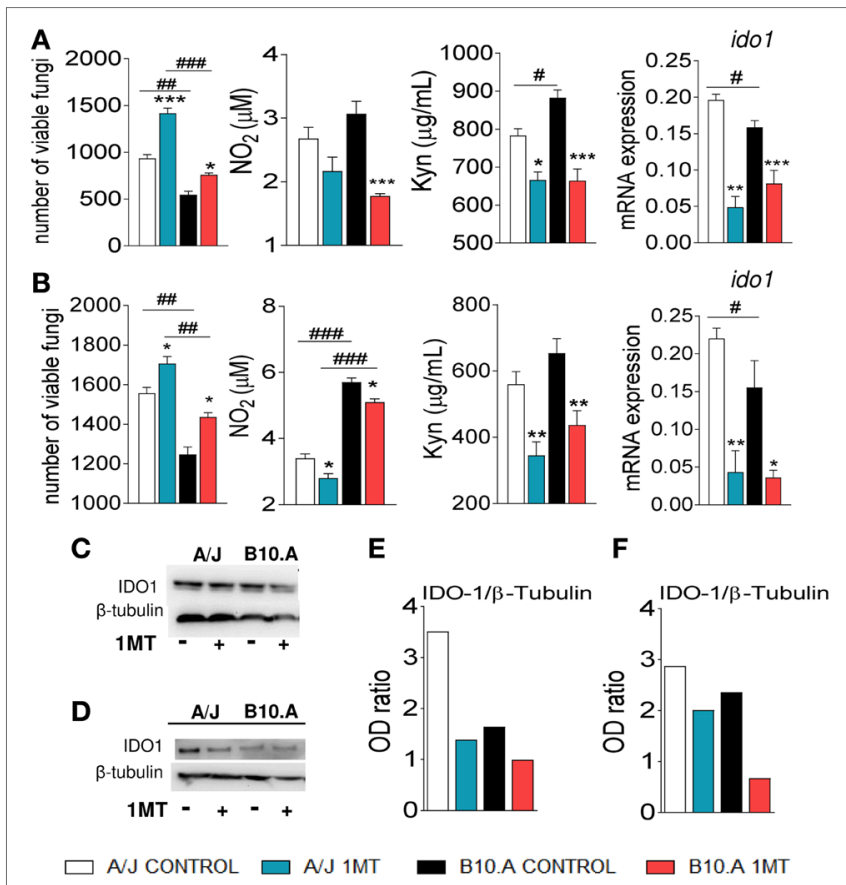

FIGURE 1 | 1-Methyl-DL-tryptophan (1MT) treatment reduces fungicidal activity, NO, kynurenine (Kyn), and indoleamine-2,3 dioxygenase (IDO) production by pulmonary dendritic cells (DCs) of Paracoccidiodes Brasiliensis-infected mice. Pulmonary DCs were obtained from $1 \mathrm{MT}$ treated or untreated $\mathrm{A} / \mathrm{J}$ and $\mathrm{B} 10 . \mathrm{A}$ mice at $96 \mathrm{~h}(\mathbf{A}, \mathbf{C}, \mathbf{E})$ and 2 weeks (B,D,F) after infection with $1 \times 10^{6}$ yeasts and cultivated for $24 \mathrm{~h}$ at $37^{\circ} \mathrm{C}$ in $5 \% \mathrm{CO}_{2}$. The cells were centrifuged, resuspended in $100 \mu \mathrm{L}$ of culture medium and assayed for the presence of viable yeasts by a CFU assay. Supernatants from DCs cultures were used to determine the levels of nitrite and Kyn. In the same experimental conditions, DCs of $\mathrm{A} / \mathrm{J}$ and B10.A mice were mixed with TRizol reagent for RNA extraction. IDO mRNA was measured using TaqMan real-time PCR assay. IDO was also characterized by immunoblotting. DCs were lysed, supernatants supplemented with a protease inhibitor and protein concentration determined by a BCA assay. After electrophoresis in

polyacrylamide gel, proteins were transferred to nitrocellulose membranes and stained with anti-IDO antisera. Densitometry of bands was performed using ImageQuant TL 8.1 software. NO production was measured by Griess reagent, and Kyn were evaluated using Ehrlich's reagent. The data represent the mean \pm SEM of three independent experiments where the asterisk $\left(^{*}\right)$ represents a statistically significant difference between treatments ${ }^{*} p<0.05$, ${ }^{\star *} p<0.01$, and $\left.{ }^{\star * \star} p<0.001\right)$ and the hashtag (\#) represents the difference between the strains ( $" p<0.05$, $\# p<0.01$, and $\left.{ }^{\# \#} p<0.001\right)$. 
confirmed by the decreased protein production as detected by Western Blotting (Figures 1C-F).

\section{IDO Inhibition Promotes Increased Influx and Activation of Pulmonary DCs}

We have then asked whether the in vivo treatment with 1MT could interfere with the number and activation of pulmonary DCs. We verified that $96 \mathrm{~h}$ and 2 weeks after infection, $1 \mathrm{MT}$-treated A/J and B10.A mice presented a higher number of myeloid, lymphoid and plasmacytoid DCs $\left(\mathrm{CD} 11 \mathrm{c}^{\text {high }} \mathrm{CD} 11 \mathrm{~b}^{+}, \mathrm{CD} 11 \mathrm{c}^{\text {high }} \mathrm{CD} 8^{+}\right.$, and $\mathrm{CD} 11 \mathrm{c}^{\text {low }} \mathrm{B} 220^{+}$, respectively) in their lungs than control mice (Figures 2A,B; Figure S1 in Supplementary Material). In addition, $1 \mathrm{MT}$ treatment increased the expression of MHC class II $\left(\mathrm{IA}^{\mathrm{K}}\right)$ and costimulatory molecules (CD86, CD40, CD11b) in pulmonary DCs obtained at both periods and mouse strains studied (Figures 2C,D). Thus, the increased fungal loads induced by $1 \mathrm{MT}$ treatment were associated with increased migration and activation of pulmonary DCs.

\section{IDO Inhibition Reduces the Secretion of DCs Cytokines}

To better evaluate the function of pulmonary DCs from 1MT-treated and untreated A/J and B10.A mice, the levels of cytokines present in the supernatants of cultivated cells were measured by ELISA. First, we could confirm our previous findings $(28,30)$ demonstrating that DCs from A/J mice produce higher levels of TGF- $\beta$ and IL-1 $\beta$ than DCs from B10.A mice that, in contrast, are better producer of IL-12 and IL-6. We have found that $1 \mathrm{MT}$ treatment reduced the levels of TGF- $\beta$ and IL- $1 \beta$ produced by A/J DCs at both postinfection periods. In contrast, reduced levels of IL-12, IL-6, and IL-1 $\beta$ were observed in $1 \mathrm{MT}$-treated B10.A mice at both time points (Figures 3A,B).

\section{IDO Inhibition Reduces the Levels of Intracellular IDO and TGF- $\beta$ in A/J DCs, whereas in B10.A DCs Diminishes the Levels of IDO, IL-12, and IL-6}

We have also characterized the effect of IDO inhibition on intracellular cytokine (TGF- $\beta$, IL-12, and IL-6) content and IDO. Purified DCs from 1MT-treated and -untreated A/J and B10.A mice obtained at two postinfection periods were cultivated and intracellular proteins analyzed by flow cytometry. Compared with untreated controls, decreased numbers of TGF- $\beta^{+}$DCs were observed in the lungs of $1 \mathrm{MT}$ treated $\mathrm{A} / \mathrm{J}$ mice. In contrast, reduced numbers of IL- $12^{+}$and IL- $6^{+}$DCs were detected in $1 \mathrm{MT}$ treated B10A mice (Figures $\mathbf{4 A , B}$ ). In addition, reduced numbers of IDO positive DCs were observed in 1MT-treated DCs from both mouse strains and postinfection periods analyzed (Figures 4A,B).

\section{IDO Inhibition Enhances the Immunogenic Activity of DCs}

Dendritic cells were isolated from 1MT-treated and untreated A/J and B10.A mice $96 \mathrm{~h}$ and 2 weeks after P. brasiliensis infection.

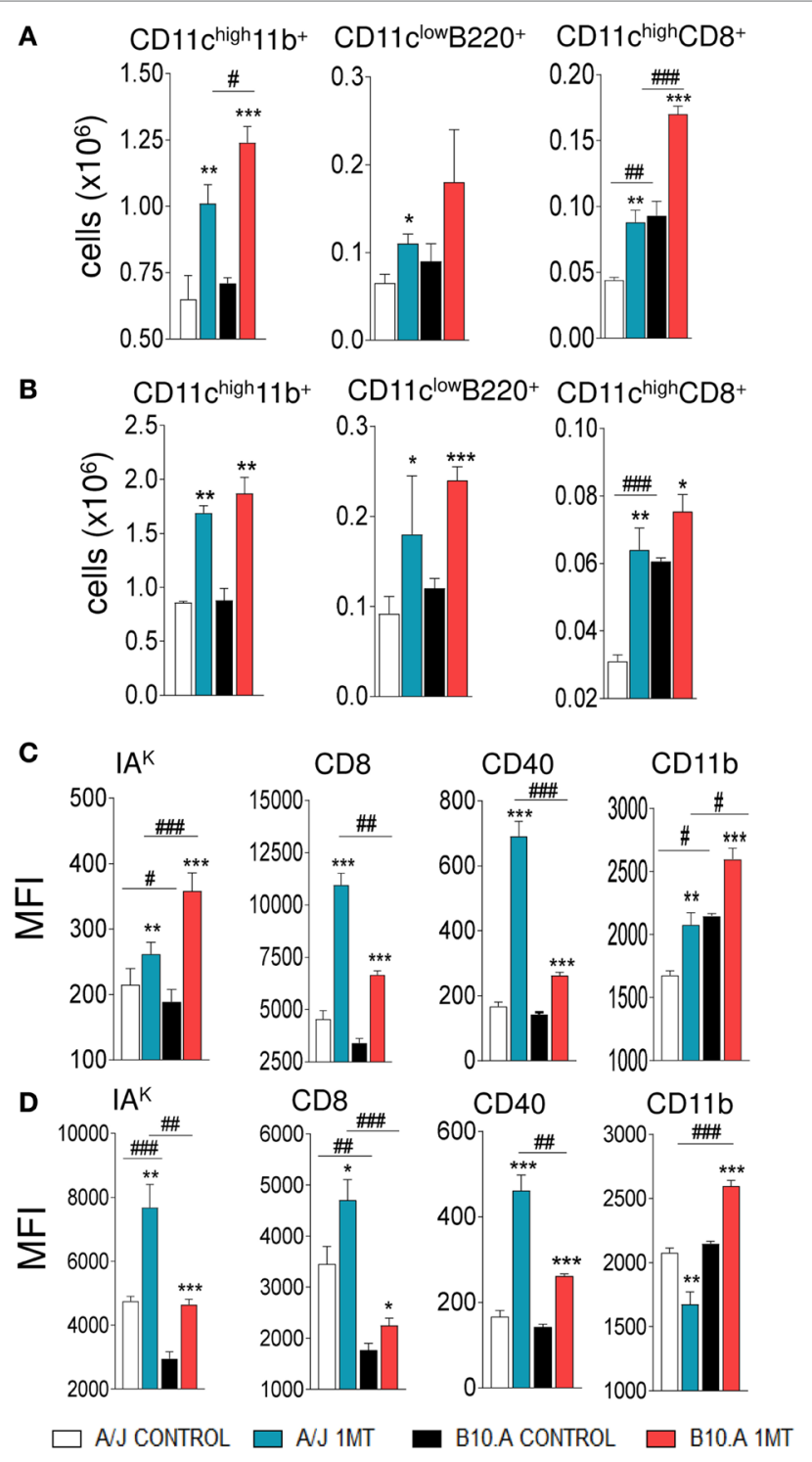

FIGURE 2 | 1-Methyl-DL-tryptophan (1MT) treatment increases the influx of activated dendritic cells (DCs) to the lungs. Number of myeloid $\left(\mathrm{CD} 11 \mathrm{c}^{\text {high }} 11 \mathrm{~b}^{+}\right)$, plasmacytoid (CD11 $\left.\mathrm{C}^{\text {low }} \mathrm{B} 220^{+}\right)$, and lymphoid $\left(\mathrm{CD} 11 \mathrm{c}^{\text {high }} \mathrm{CD}^{+}\right)$DCs obtained $96 \mathrm{~h}$ (A) and 2 weeks (B) after infection of $1 \mathrm{MT}$-treated and -untreated $\mathrm{A} \mathrm{J}$ and B10.A mice with $1 \times 10^{6}$ viable Paracoccidiodes brasiliensis yeasts. Median fluorescence intensity (MFI) of $I^{K}$, CD86, CD11b, and CD40 expressed by DCs obtained from lungs of AVJ and B10.A mice $96 \mathrm{~h}$ (C) and 2 weeks (D) after infection. DCs were obtained by fractionation with anti-CD11c magnetic beads and DCs phenotyping determined by flow cytometry. The data represent the mean \pm SEM of three independent experiments where the asterisk $\left(^{\star}\right)$ represents a statistically significant difference between treatments $\left({ }^{*} p<0.05\right.$, ${ }^{* *} p<0.01$, and $\left.{ }^{* * *} p<0.001\right)$ and the hashtag (\#) represents the difference between the

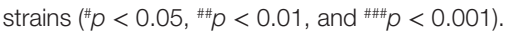

In parallel, splenic lymphocytes from uninfected A/J and B10. A mice were obtained, labeled with CFSE, and cocultured with purified DCs. After 3 days, the proliferation of lymphocytes was analyzed by flow cytometry and the levels of IFN- $\gamma$ and IL- 2 were measured in culture supernatants. 


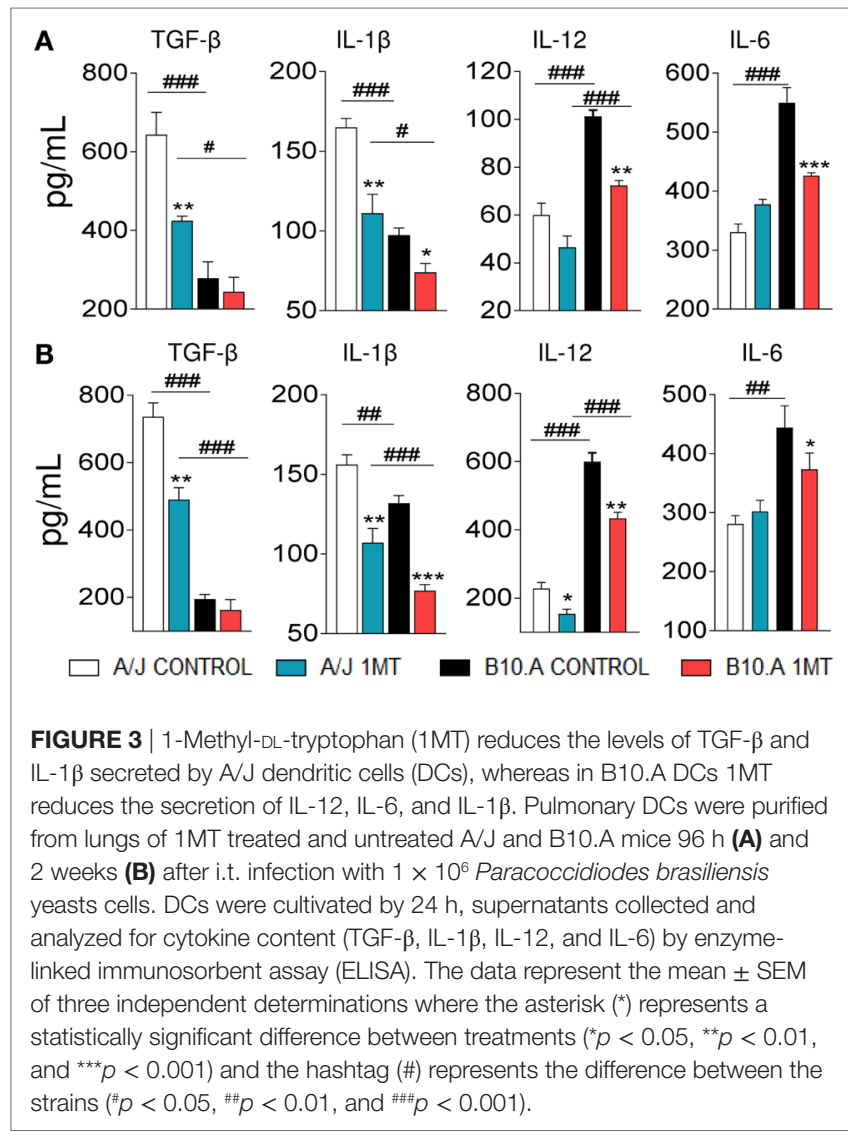

As previously described with untreated pulmonary DCs (30), DCs from 1MT-treated and untreated A/J mice obtained at both postinfection periods induced higher lymphoproliferation than those of B10.A mice (Figures 5A,B). However, for both mouse strains at both periods assayed, the inhibition of IDO activity resulted in increased proliferation of lymphocytes. In cultures of $1 \mathrm{MT}$ treated or untreated naive lymphocytes no cell proliferation was observed. In the same way, no observe lymphoproliferation were detected when $1 \mathrm{MT}$ treated or untreated DCs from uninfected mice were used as APC. The levels of IFN- $\gamma$ and IL-2 were measured in the supernatants of lymphoproliferation assays. Compared with untreated controls, decreased levels of IFN- $\gamma$ were observed in 1MT-treated DCs from B10.A mice, whereas increased levels of IL-2 were detected in 1MT-treated DCs of both mouse strains and postinfection periods (Figures 5A,B).

\section{IDO Inhibition Expands CD4 ${ }^{+}$and CD8 ${ }^{+}$ T Cells and Reduces Treg Cells}

Treatment of B10.A and A/J mice with $1 \mathrm{MT}$ increased the differentiation of $\mathrm{T}$ cells induced by isolated DCs. Indeed, increased frequency of naive $\mathrm{CD}^{+}$and $\mathrm{CD}^{+}\left(\mathrm{CD} 4^{+} \mathrm{CD} 44^{\text {low }}{ }^{\mathrm{CD}} 62 \mathrm{~L}^{\text {high }}\right.$ and $\mathrm{CD} 8{ }^{+} \mathrm{CD} 44^{\text {low }} \mathrm{CD} 62 \mathrm{~L}^{\text {high }}$, respectively) as well as memory/ effector $\mathrm{CD}^{+}$and $\mathrm{CD}^{+} \quad\left(\mathrm{CD} 4^{+} \mathrm{CD} 44^{\text {high }} \mathrm{CD}^{+} 2 \mathrm{~L}^{\text {low }}\right.$ and $\left.\mathrm{CD} 8^{+} \mathrm{CD} 44^{\text {high }} \mathrm{CD}^{2} \mathrm{~L}^{\text {low }}\right) \mathrm{T}$ cells were detected when $1 \mathrm{MT}$-treated DCs were cocultivated with naive lymphocytes (Figures 6A,B).

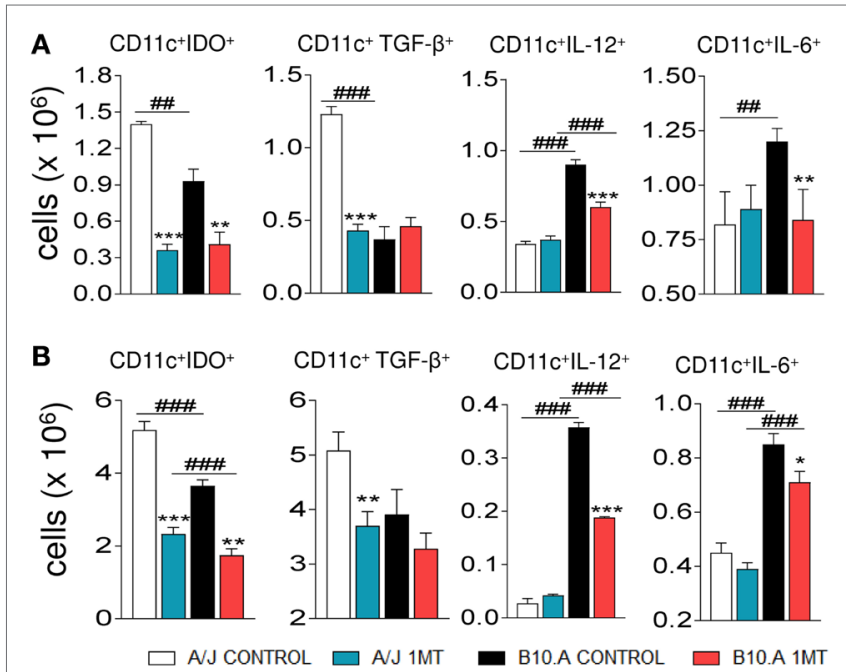

FIGURE 4 | 1-Methyl-DL-tryptophan (1MT) treatment reduces the number of TGF- $\beta^{+}$dendritic cells (DCs) in the lungs of $A / J$ mice but reduces $\mathrm{IL}-12^{+}$and IL-6+ DCs in B10.A mice. Number of pulmonary DCs expressing intracellular indoleamine-2,3 dioxygenase (IDO), TGF- $\beta$, IL-12, and IL-6, 96 h (A) and 2 weeks (B) after Paracoccidiodes brasiliensis infection. Lungs of $1 \mathrm{MT}$ treated and untreated $\mathrm{A} / \mathrm{J}$ and B10.A-infected mice were excised and DCs cells purified by magnetic beads. The expression of intracellular cytokines was analyzed by flow cytometry. The data represent the mean \pm SEM of three independent determinations where the asterisk $\left(^{*}\right)$ represents a statistically significant difference between treatments $\left({ }^{*} p<0.05\right.$, ${ }^{\star *} p<0.01$, and $\left.{ }^{* *} p<0.001\right)$ and the hashtag (\#) represents the difference between the strains $(\# \#<0.01$ and $\# \# p<0.001)$.

Accordingly, reduced frequencies of Treg $\left(\mathrm{CD} 4^{+} \mathrm{CD} 25^{+} \mathrm{FoxP} 3^{+}\right)$ cells were observed when DCs were obtained from 1MT-treated resistant and susceptible mice (Figures 6C,D).

\section{IDO Is Regulated by IFN- $\gamma$ in B10.A Mice and TGF- $\beta$ in $A / J$ Mice}

Two opposite pathways were shown to regulate the production and activity of IDO. The IDO-IFN- $\gamma$ axis is associated with the catalyst function of this enzyme, leads to trp starvation and Kyn production that in turn control pathogen growth and the inflammatory response. In contrast, the TGF- $\beta$-IDO axis has been linked with a signaling function of pIDO that promotes the differentiation of tolerogenic DCs and increases the expansion of Treg cells $(12,35,36)$.

We speculated that in B10.A mice IDO is mainly catalyst and IFN- $\gamma$-regulated, whereas in $\mathrm{A} / \mathrm{J}$ mice IDO has a predominant signaling function induced by TGF- $\beta$. To explore this hypothesis, the expression of genes and proteins related to IFN- $\gamma$ and TGF- $\beta$ signaling pathways was characterized in DCs of $1 \mathrm{MT}$-treated and untreated B10.A and A/J mice obtained at $96 \mathrm{~h}$ (Figures S3 and S4 in Supplementary Material) and 2 weeks of infection. As shown in Figure 7A, DCs from B10.A mice expressed higher levels of mRNA from genes associated with IFN- $\gamma$ signaling. Therefore, $1 \mathrm{MT}$ treatment led to a marked reduction in the expression of IFN- $\gamma$, Jak1, Stat1, IL-6, SOCS3, and NOS2 mRNA by DCs from B10.A mice but had a minor effect on DCs of A/J mice (Figure 7A). 


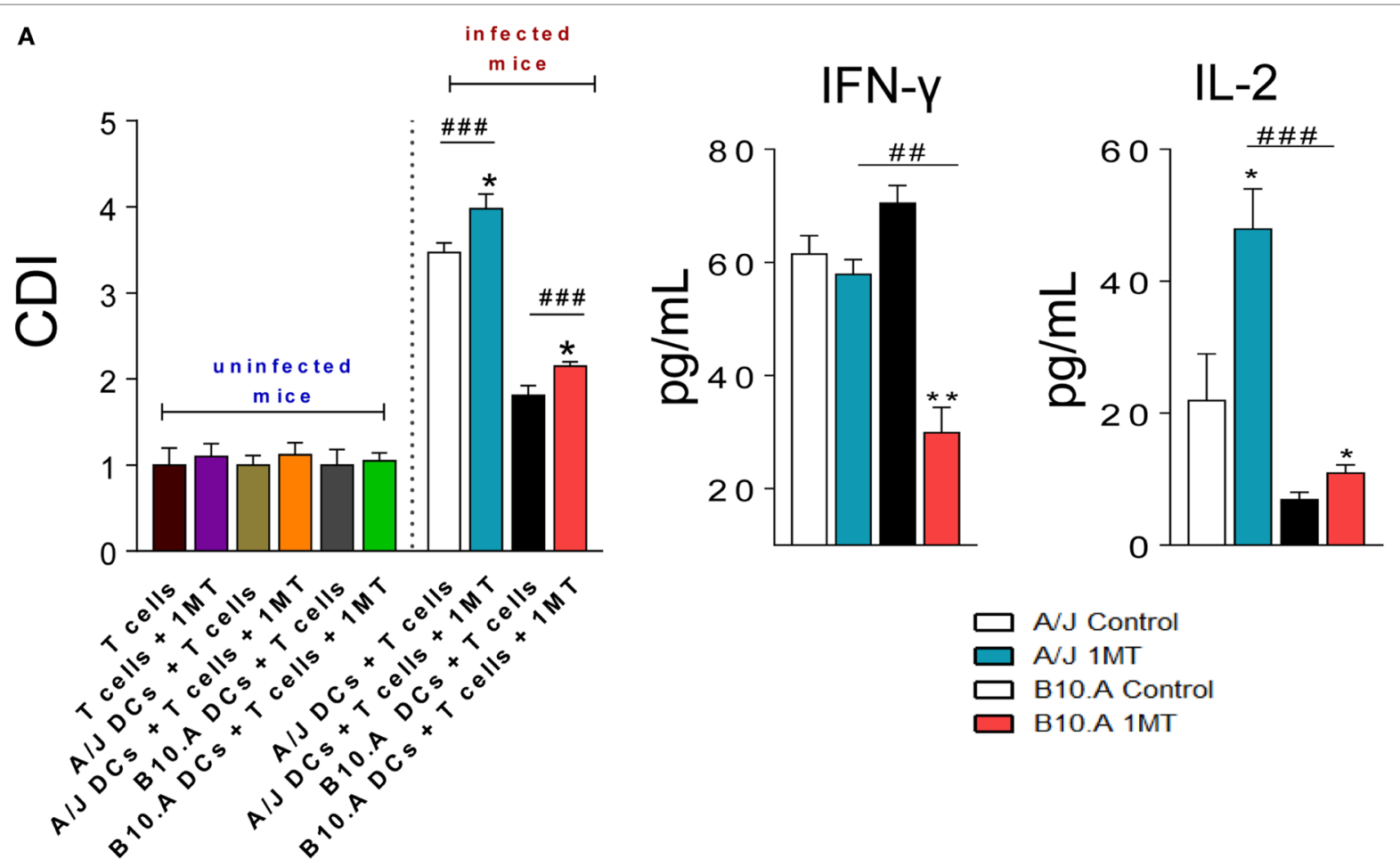

в
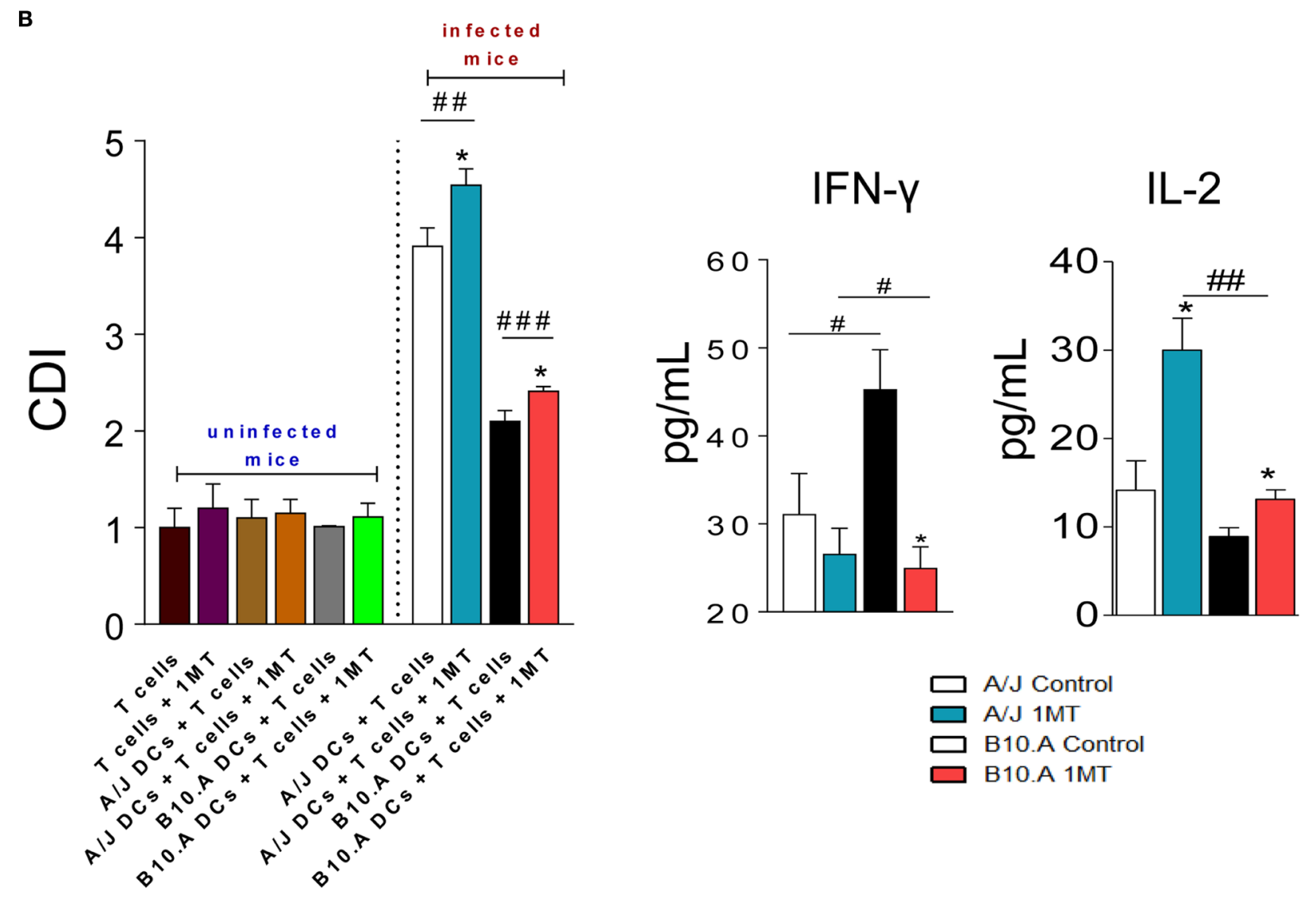
FIGURE 5 | Continued

1-Methyl-DL-tryptophan (1MT) treatment increases the immunogenicity of dendritic cells (DCs). Pulmonary DCs were obtained from lungs of $1 \mathrm{MT}$-treated and -untreated A/J and B10.A mice $96 \mathrm{~h}$ (A) and 2 weeks (B) after infection with $1 \times 10^{6}$ Paracoccidiodes brasiliensis yeasts using anti-DC11C magnetic beads. Spleen lymphocytes from non-infected A/J and B10.A mice were obtained, labeled with CFSE $(5 \mathrm{mM})$ and cocultivated with DCs, in a ratio of DC:lymphocyte of $1: 10$. In parallel, pulmonary DCs from uninfected $\mathrm{A} / \mathrm{J}$ and B10.A mice were obtained using anti-DC11c magnetic beads and cultured with $1 \mathrm{MT}$ treated or untreated naive lymphocytes from non-infected $\mathrm{A} / \mathrm{J}$ and B10.A mice. After 3 days of cocultivation, the cells were adjusted to $1 \times 10^{6}$, labeled with specific anti-CD4 (A) and anti-CD8 (B) antibodies and analyzed by flow cytometry. The cell division index (CDI) was calculated as previously described by Mannering et al. (34) and was based on the number of $\mathrm{CFSE}^{+} \mathrm{CD} 4^{+}$or $\mathrm{CFSE}^{+} \mathrm{CD} 8^{+} \mathrm{T}$ cells found in the stimulated culture/number of $\mathrm{CFSE}^{+} \mathrm{CD}^{+}{ }^{+}$or $\mathrm{CFSE}^{+} \mathrm{CD} 8^{+} \mathrm{T}$ cells in the unstimulated culture. The lymphocyte population was gated by FSC/SSC analysis. Fifty thousand cells were counted, and the data expressed as frequency of positive cells. Results are representative of three independent experiments. Cytokines were measured in culture supernatants by enzyme-linked immunosorbent assay (ELISA). The data represent the mean \pm SEM of three independent determinations where the asterisk $\left(^{\star}\right)$ represents a statistically significant difference between treatments $\left({ }^{*} p<0.05\right.$ and $\left.{ }^{* *} p<0.01\right)$ and the hashtag $(\#)$ represents the difference between the strains $\left(\# \#<0.01\right.$ and $\left.{ }^{\# \# \# ~} p<0.001\right)$.
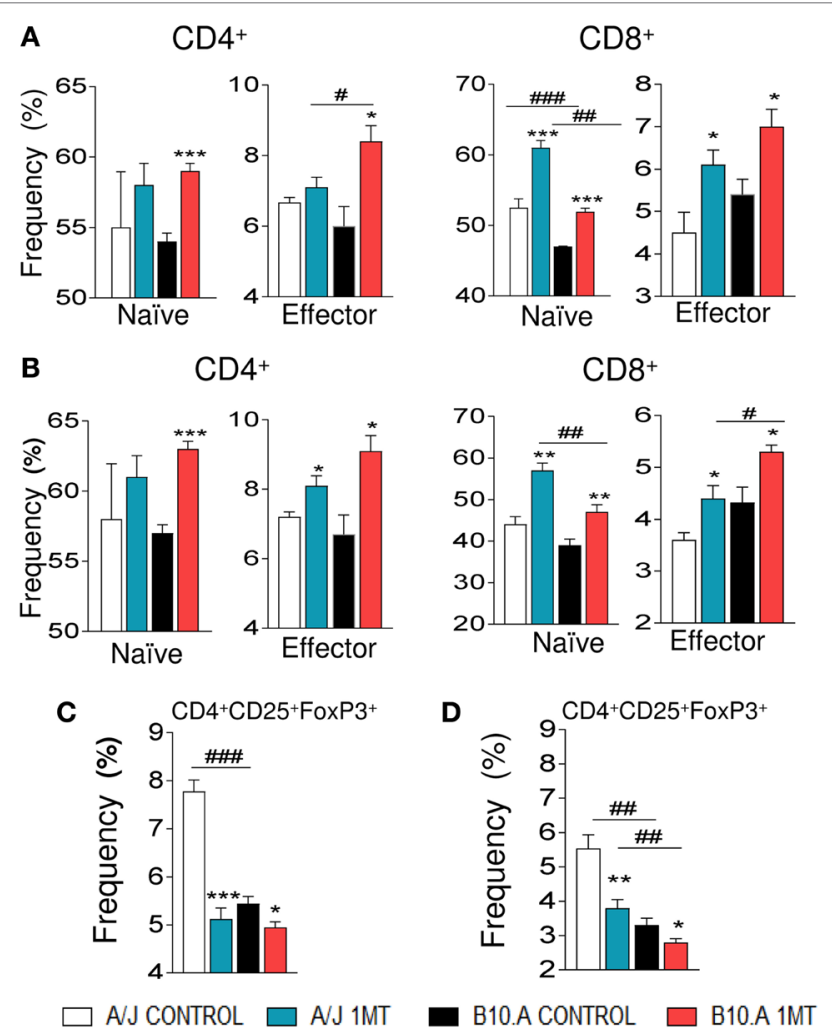

FIGURE 6 | 1-Methyl-DL-tryptophan (1MT) increases proliferation of CD4+ and $\mathrm{CD}^{+} \mathrm{T}$ cells and reduces regulatory $\mathrm{T}$ cells (Tregs). Spleen lymphocytes from uninfected $\mathrm{A} / \mathrm{J}$ and B10.A mice were labeled with CFSE (5 mM) and cocultivated with purified dendritic cells (DCs) obtained from $1 \mathrm{MT}$ treated and untreated $\mathrm{A} / \mathrm{J}$ and B10.A mice infected i.t. with $1 \times 10^{6}$ of Paracoccidiodes brasiliensis yeasts. DCs were obtained at $96 \mathrm{~h}$ and 2 weeks postinfection, and cocultivated with CFSE labeled lymphocytes at a ratio of DC:lymphocyte of 1:10. After 3 days, the cells were adjusted to $1 \times 10^{6}$, labeled with specific anti-CD4, -CD8, -CD44, -CD62L, -CD25,

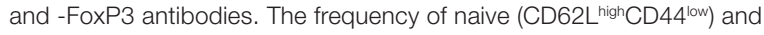
effector/memory (CD62 Low $\left.^{\text {low }} 44^{\text {high }}\right) \mathrm{CD}^{+}$and $\mathrm{CD} 8^{+} \mathrm{T}$ cells as well as CD4 ${ }^{+} \mathrm{CD} 25^{+}$FoxP3 regulatory $T$ cells (Tregs) was measured by flow cytometry. Values are the mean of three independent experiments. The asterisks represent statistically significant differences between treatments $\left({ }^{\star} p<0.05,{ }^{\star \star} p<0.01\right.$, and $\left.{ }^{* \star *} p<0.05\right)$. The hashtag marks represent statistically significant differences between strains $\left(\# p<0.05,{ }^{\#} p<0.01\right.$, $\#$ \#\# 0.001$)$.

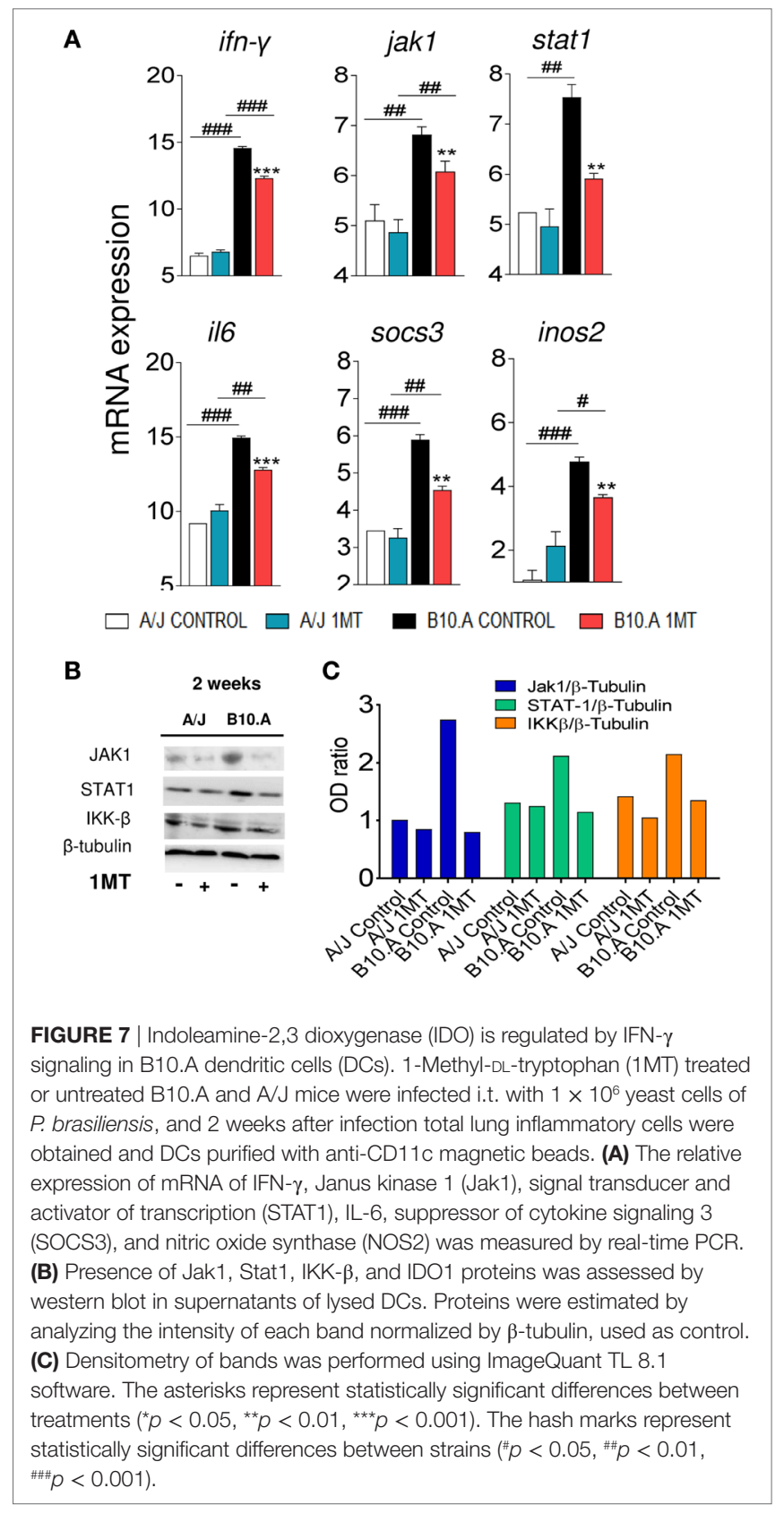


These findings indicate that in B10.A mice the IDO function is mainly catalyst and regulated by IFN- $\gamma$. Immunoblotting assays confirmed these results, and increased amounts of JAK1, STAT1 , and IKK- $\beta$ proteins were found in DCs extracts of B10.A DCs (Figures 7B,C). In contrast to B10.A mice, DCs from A/J mice express higher levels of mRNA from genes associated with TGF$\beta$ signaling (Figure 8). Compared with B10.A DCs, cells from $\mathrm{A} / \mathrm{J}$ mice expressed increased levels of TGF- $\beta$, SMAD2, SMAD3, SHIP1, SHP1, SHP2, IFN- $\alpha$, and IFN- $\beta$ mRNA. 1MT treatment significantly reduced these levels in A/J DCs but had no effect on B10.A cells (Figure 8A). Assessing protein production, increased

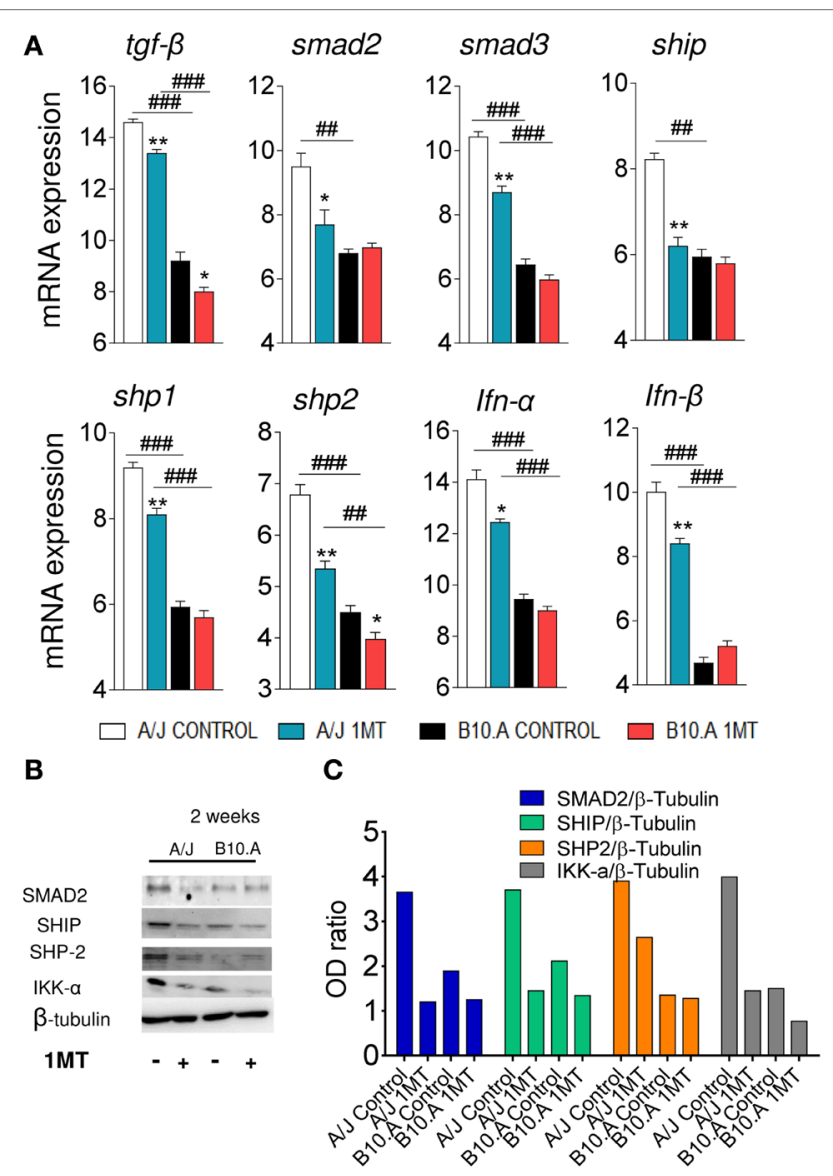

FIGURE 8 | Indoleamine-2,3 dioxygenase (IDO) is regulated by TGF- $\beta$ signaling in $\mathrm{A} / \mathrm{J}$ dendritic cells (DCs). 1-Methyl-DL-tryptophan (1MT)-treated or -untreated B10.A and A/J mice were infected i.t. with $1 \times 10^{6}$ Paracoccidiodes brasiliensis yeasts and 2 weeks after infection total lung inflammatory cells were obtained and DCs purified by anti-CD11c magnetic beads. (A) The relative expression of mRNA of TGF- $\beta$, Smad2, Smad 3, SHIP, SHP-1, SHP-2, IFN- $\alpha$, and IFN- $\beta$ was measured by real-time PCR (B) Smad2, Ship, Shp-2, IKK- $\alpha$ and IDO1, and pIDO protein expression was assessed by western blot in supernatants of lysed DCs. (C) Proteins were estimated by analyzing the intensity of each band normalized by $\beta$-tubulin, used as control. Densitometry of bands was performed using ImageQuant TL 8.1 software. Values are the mean \pm SEM of three independent experiments; the asterisks represent statistically significant differences between treatments $\left({ }^{\star} p<0.001,{ }^{* \star} p<0.01,{ }^{\star \star \star} p<0.05\right)$. The hash marks represent statistically significant differences between strains $(\# p<0.05$, $\# p<0.01, \# \#<0.001)$. amounts of SMAD2, SHIP1, SHP2, and IKK- $\alpha$ were observed in extracts of A/J DCs (Figures 8B,C).

\section{A/J Mice pIDO and Use the Non-Canonical Pathway of NF-кB Activation, whereas B10.A Mice Express Non-pIDO and Use the Canonical Pathway of NF-кB Activation}

Because IFN- $\gamma$ signaling is mainly associated with the canonical pathway of NF- $\kappa \mathrm{B}$ activation, the transcriptional activity of p65 and p50 were measured by ELISA in the nuclear extracts of 1MT-treated and -untreated DCs. As depicted in Figure 9A, DCs from B10.A mice showed increased expression of nuclear

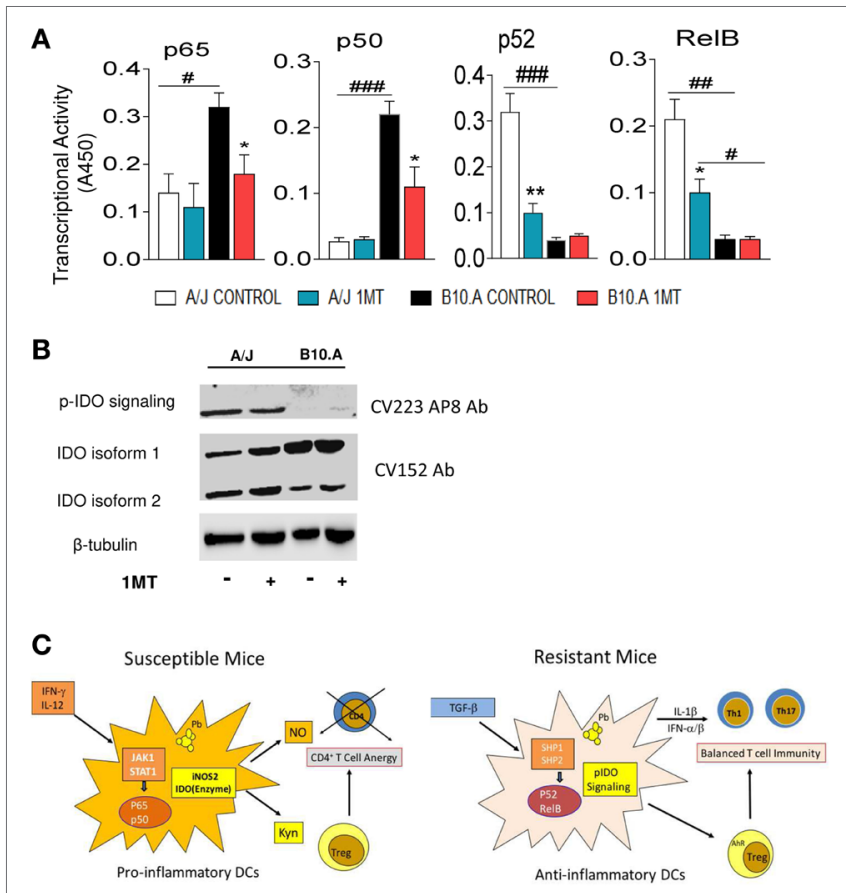

FIGURE 9 | Phosphorylated indoleamine-2,3 dioxygenase (pIDO) of A/J mice activate the non-canonical pathway of NF-kB, whereas in B10.A dendritic cells (DCs) non-phosphorylated IDO use the canonical pathway of NF-kB activation. (A,B) Quantitation of p65, p50, p52, and RelB by enzyme-linked immunosorbent assay (ELISA) in nuclear extracts of DCs. Results are presented as absorbance at $450 \mathrm{~nm}$ (A450). Values are the mean \pm SE of three independent experiments. The asterisks represent statistically significant differences between treatments $\left({ }^{*} p<0.05,{ }^{* *} p<0.01\right.$,

$\left.{ }^{\star \star *} p<0.001\right)$. The hash marks represent statistically significant differences between strains $(\# p<0.05, \# p<0.01, \# \# p<0.001)$. (C) Expression of IDO and phosphorylated IDO was assessed by Western blot in lung homogenates of $1 \mathrm{MT}$ treated and untreated B10.A and AVJ mice i.t. infected with $1 \times 10^{6}$

Paracoccidiodes brasiliensis yeasts. pIDO was revealed by a specific antibody that recognizes the phosphorylated ITIM moiety of IDO (CV223 AP8) and the enzyme IDO by a specific monoclonal antibody (CV152). (D) In susceptible B10.A mice, IDO is induced by IFN- $\gamma$ that activates the canonical pathway of NF-kB and enhanced INOS and IDO expression resulting in anergy of $\mathrm{T}$ cell immunity. In resistant A/J mice, TGF- $\beta$ signaling induces the non-canonical pathway of NF-kB activation and continuous synthesis of TGF- $\beta$ that confers an stable tolerogenic behavior to DCs that control immunity and tissue pathology. 
p65 and p50 than those of A/J mice. Furthermore, 1MT treatment reduced this production by B10.A DCs (Figure 9A). An equivalent result was observed with DCs obtained at $96 \mathrm{~h}$ of infection (Figure S1 in Supplementary Material). The prevalent non-canonical activation of NF- $\mathrm{KB}$ by A/J DCs was confirmed by the increased levels of nuclear p52 and RelB produced in comparison with B10.A DCs (Figure 9A). Treatment with $1 \mathrm{MT}$ caused a significant reduction of p52 and RelB only in A/J DCs. Again, an equivalent result was observed in pulmonary DCs obtained at $96 \mathrm{~h}$ of infection (Figure S2 in Supplementary Material). To further confirm the signaling function of IDO, lung extracts from $1 \mathrm{MT}$ treated and untreated B10.A and A/J mice were obtained 2 weeks after infection and the expression of pIDO was assessed by immunoblotting using a specific mAb (CV223 AP8 Ab) that recognizes the phosphorylated moiety of ITIM. As depicted in Figure 9B, only A/J mice express pIDO and 1MT treatment did not affect the production of this molecule. Using a polyclonal antibody to IDO (CV152 Ab) two isoforms of IDO, and the elevated expression of the isoform 1 by B10.A DCs were seen. The Figure 9C summarizes the main findings obtained in this study. In susceptible B10.A mice IDO is induced by IFN- $\gamma$ that activates the canonical pathway of NF- $\mathrm{\kappa B}$ and enhanced iNOS and IDO expression resulting in anergy of T cell immunity. In resistant $\mathrm{A} / \mathrm{J}$ mice, TGF- $\beta$ signaling induces the non-canonical pathway of NF- $\kappa \mathrm{B}$ activation and continuous synthesis of TGF- $\beta$ that confers an stable tolerogenic behavior to DCs that control immunity and tissue pathology.

\section{DISCUSSION}

The antimicrobial and immunoregulatory functions of IDO have been recognized as central mechanisms used by infected hosts to control pathogen growth and excessive inflammatory responses $(37,38)$. Both IDO activities were used by resistant and susceptible mice to control pulmonary PCM. However, only in susceptible mice IDO inhibition caused a sustained fungal growth, exacerbated tissue pathology and increased mortality rates. This is the worst scenario for host fitness because it allies uncontrolled pathogen growth with exacerbated, but inefficient, inflammation resulting in warful tissue destruction. These findings led us to further investigate the role of IDO in the resistance mechanisms to pulmonary PCM. We found the IDO inhibitor 1-MT as two stereoisomers, 1-D-MT and 1-LMT. Most of the studies using the IDO enzyme model employed the racemic mixture 1-DL-MT to inhibit the enzime, independent of the known IDO isoforms, IDO1 and IDO2, as we did in this work. Indeed, recent studies have shown that IDO1 is the preferentially inhibited by1-L-MT, while 1-D-MT inhibits IDO2 $(39,40)$. These findings directed our subsequent studies on the inhibition of IDO using deficient mice, as we have shown in recent work with IDO1-deficient (IDO1 $1^{-/-}$) C57BL/6 mice (41). Using isolated pulmonary DCs, we verified that IDO inhibition led to increased recovery of yeasts from both $\mathrm{A} / \mathrm{J}$ and B10.A cells. This finding could be attributed to the increased trp availability (42-44), but also to the reduced NO production, an important fungicidal mechanism of macrophages and DCs $(26,27,30)$.
Interestingly, IDO inhibition by $1 \mathrm{MT}$ reduced the typical cytokines that characterize the innate response of B10.A and A/J mice $(26,27,30)$. Furthermore, the assessment of intracellular cytokines has further emphasized the higher expression of IDO and TGF- $\beta$ by A/J DCs, whereas the proinflammatory cytokines IL-12 and IL-6 were more expressed by B10.A DCs. This led us to suppose that IDO activity in B10.A mice was mainly catalytic, whereas in A/J mice was predominantly signaling and involved in signal transduction (12). These investigators clearly demonstrated that TGF- $\beta$ signaling activates the tyrosine kinase Fyn that phosphorylates ITIM domains of IDO. This promotes the association of IDO with tyrosine phosphatases (SHP1 and SHP2) that results in the activation of the non-canonical NF- $\kappa$ B pathway (p52/RelB), which translocates to the nucleus and induces the production of type I IFNs (IFN $\alpha / \beta$ ), TGF- $\beta$, and IDO (12).

An increased number of activated DCs with enhanced immunogenic activity was detected in the lungs of $1 \mathrm{MT}$ treated mice. The increased proliferation of naive lymphocytes was concomitant with increased levels of IL-2 in A/J cocultures and decreased IFN- $\gamma$ production by B10.A cells mirroring the main suppressive mechanisms developed by susceptible and resistant mice $(25,26$, $30,45)$. This enhanced immunogenic activity was further confirmed by the increased proliferation of naive and effector/ memory $\mathrm{CD}^{+}$and $\mathrm{CD}^{+} \mathrm{T}$ cells concomitant with a reduced expansion of $\mathrm{CD} 4^{+} \mathrm{CD} 25^{+} \mathrm{Foxp}^{+}$Treg cells, a finding that may be also associated with the reduced levels of suppressive Kyn produced $(46,47)$. This tolerogenic function of Kyn on T cells has been linked to the activation of the AhR, a ligand activated transcription factor $(46,48)$ that participates in the pIDO-tolerogenic DCs-Treg loop of immunoregulation.

Further assessing the mechanisms involved in the divergent activities of IDO, a preferential IFN- $\gamma$ signaling pathway was observed in B10.A DCs which expressed increased levels of IFN- $\gamma$ and Jak1-Stat 1 mRNA. In addition, elevated expression of IL-6, SOCS3, and iNOS2 were also observed indicating a prevalent IFN- $\gamma$-mediated catalytic activity. These data were further confirmed by the increased synthesis of Stat 1 and IKK $\beta$ proteins involved in IFN- $\gamma$ signaling. The striking expression of IL- 6 and SOCS3 suggests that in susceptible mice IDO degradation may occur via proteasomal activity (49). Our data have also confirmed the prevalent TGF- $\beta$-mediated activation of A/J DCs which express high levels of TGF- $\beta$, Smad2, Smad3, Ship1, Shp1, Shp 2 , IFN- $\alpha$, and IFN- $\beta$ mRNA. The high levels of IKK- $\alpha$, Smad2, Ship1, and Sph-2 proteins expressed by these cells have further confirmed the use of the TGF- $\beta$ signaling by DCs from resistant mice. These data agree with the signaling cascade that promotes a tolerogenic activity in plasmacytoid DCs previously described (12) and explain the continuous production of TGF- $\beta$ by A/J mice that favors the conversion of naive $\mathrm{CD} 4^{+} \mathrm{T}$ cells into Treg cells (25). Interestingly, the inhibition of IDO by $1 \mathrm{MT}$ showed little interference with the TGF- $\beta$-mediated pathway used by A/J DCs, demonstrating that the signaling function of the IDO has predominance over the catalytic activity.

The predominant expression of p65 and p50 by B10.A DCs and the higher levels of p52 and RelB by A/J DCs showed that B10.A and $\mathrm{A} / \mathrm{J}$ mice predominantly use, respectively, the canonical and non-canonical pathways of NF- $\kappa \mathrm{B}$ activation by their pulmonary 
DCs. More importantly, we could demonstrate the presence of pIDO in the lungs of A/J mice, whereas the non-phosphorylated forms of IDO were observed in B10.A mice. Therefore, we could clearly demonstrate that in B10.A mice IDO has a catalytic function, whereas in A/J mice, besides its enzymatic activity, IDO has a signaling function.

Similarly with other infection models, our studies in experimental PCM showed that the balanced activation of the immune system is fundamental for the protection of hosts, and the excessive activation of pro- or anti-inflammatory mechanisms leads to severe disease $(23,29,50,51)$. In susceptible mice, the suppression of adaptive immunity is a consequence of excessive proinflammatory activity of innate immunity, which, however, is able to control the initial fungal burden. In resistant mice, in contrast, an anti-inflammatory, TGF- $\beta$ dominated activity is observed impairing the initial control of fungal growth. This activity, however, is balanced by the marked dectin-1 and NLRP3 activation and synthesis of TNF- $\alpha$ and IL- $1 \beta$ by A/J macrophages. This pattern of response leads to the subsequent differentiation of Th1/Th17 mixed responses, always strongly controlled by elevated numbers and activity of Treg cells that control tissue pathology $(24-27,29)$. This is an unusual but interesting model of resistance and susceptibility to a primary fungal pathogen not previously described.

Host defenses are governed by resistance and tolerance mechanisms, the first involved in reducing pathogen burden during infection and the latter associated with mechanisms that protected the hosts from pathogen- or immune-induced damage. These mechanisms are not mutually exclusive and both can contribute to host fitness $(52,53)$. Our studies clearly demonstrate that the resistance mechanisms used by A/J mice are governed by resistance to disease and not resistance to pathogen growth. Although not intensely explored in infectious diseases, tolerance to disease is well known and described in plant pathology where host protection is not achieved by the elimination of the pathogen, but it is based on the control of host fitness. This response allows pathogen persistence, but its excessive growth is partially controlled by immune mechanisms that are tightly regulated to preserve homeostasis (52). This is also observed in the host responses to commensal fungi such as Aspergillus fumigatus and Candida albicans that concomitantly control fungal burden and tissue inflammation (50). The important influence of the IDOAhR-Treg-Th17 axis on the control of this well-balanced response to commensal microorganisms has been well described in the literature $(44,54,55)$. The IFN- $\gamma$-mediated activation of IDO and Kyn synthesis by tissue DCs confers a tolerogenic profile to these cells that promote the differentiation of naive $\mathrm{T}$ cells into Foxp $3^{+}$Treg cells via activation of AhR that prevents the excessive expansion of Th17 lymphocytes $(44,56)$. This tightly regulated immunity confers immune homeostasis that results in microbial resistance but avoids tissue pathology. The signaling property of pIDO induced by TGF- $\beta$ activation of DCs was more recently described and has been viewed as potent immunoregulatory mechanism that confer stable tolerogenic activity to plasmacytoid DCs $(12,36)$. This tolerogenic mechanism was validated in an in vivo model of delayed-type hypersensitivity response and in the protective activity of endotoxin-tolerant state of mice against
Gram-positive and Gram-negative infections $(12,54)$. However, to our knowledge, this mechanism of disease tolerance was never described in the host responses to primary fungal pathogens. Indeed, pIDO-mediated tolerance was poorly explored in infectious pathologies. Therefore, we believe that the findings here described open new perspectives to understand resistance against PCM and other primary fungal pathogens where excessive inflammation has been associated with severe disease $(57,58)$. Previous results obtained in our experimental model, not well understood when originally obtained, can now be re-evaluated in face of the IDO mediated mechanism here described. The subcutaneous immunization with viable yeasts confers sterile immunity to i.p. challenged B10.A mice but partial immunoprotection in $\mathrm{A} / \mathrm{J}$ mice that remain with persistent fungal loads $(59,60)$. We have also previously described that $P$. brasiliensis infection induces an elevated production of TGF- $\beta$ and M 2 differentiation of $\mathrm{A} / \mathrm{J}$ macrophages which express high levels of arginase (27), another finding which is not in line with the mechanisms of pathogen resistance usually described. However, this finding may now be better appreciated and understood because arginase expression by innate immune cells was reported to be essential for the differentiation of tolerogenic DCs, whose signaling activity is mediated by pIDO (61).

In conclusion, the studies here reported clearly demonstrate that susceptibility to PCM is mainly mediated by the proinflammatory IFN- $\gamma$-IDO axis of innate responses, whereas resistance relies on the initial anti-inflammatory TGF- $\beta$-pIDO-Treg axis that confers a sustained tolerogenic phenotype in pulmonary DCs allowing $\mathrm{A} / \mathrm{J}$ mice to interact with a primary fungal pathogen as a commensal microbe. Therefore, the signaling function of $\mathrm{pIDO}$ leads to an efficient fungus--host interaction that conditions advantages to both partners, and may be explored in further innovative anti-fungal therapy.

\section{ETHICS STATEMENT}

The experiments were performed in strict accordance with the Brazilian Federal Law 11,794 establishing procedures for the scientific use of animals, and the State Law establishing the Animal Protection Code of the State of São Paulo. All efforts were made to minimize animal suffering. The procedures were approved by the Ethics Committee on Animal Experiments of the Institute of Biomedical Sciences of University of São Paulo (Proc.180/11/ CEEA).

\section{AUTHOR CONTRIBUTIONS}

EA designed, conducted, and analyzed all experiments. FL, CF, and TC performed and analyzed experiments. CV characterized IDO and IDO phosphorylation. LR provided conceptual help and wrote the article. PP provided conceptual help and precious reagents for IDO analysis. VC planned experiments, supervised the overall study, and wrote the manuscript.

\section{FUNDING}

This work was supported by grants from the Fundação de Amparo à Pesquisa do Estado de São Paulo (FAPESP) 
research grants no. 2011/51258-2 (VLGC) and 2016/04783-2 (FVL); FAPESP postdoctoral felowships no. 2013/02396-9 (CF) and 2014/18668-0 (EFA); and Conselho Nacional de Pesquisas (CNPq) research grant no. 4713172012 (VLGC).

\section{REFERENCES}

1. Mellor AL, Munn DH. IDO expression by dendritic cells: tolerance and tryptophan catabolism. Nat Rev Immunol (2004) 4:762-74. doi:10.1038/nri1457

2. Grohmann U, Fallarino F, Puccetti P. Tolerance, DCs and tryptophan: much ado about IDO. Trends Immunol (2003) 24:242. doi:10.1016/S14714906(03)00072-3

3. von Bergwelt-Baildon MS, Popov A, Saric T, Chemnitz J, Classen S, Stoffel MS, et al. CD25 and indoleamine 2,3-dioxygenase are up-regulated by prostaglandin E2 and expressed by tumor-associated dendritic cells in vivo: additional mechanisms of T-cell inhibition. Blood (2006) 108:228-37. doi:10.1182/ blood-2005-08-3507

4. Popov A, Schultze JL. IDO-expressing regulatory dendritic cells in cancer and chronic infection. JMol Med (2008) 86:145-60. doi:10.1007/s00109007-0262-6

5. Braun D, Longman RS, Albert ML. A two-step induction of indoleamine 2,3 dioxygenase (IDO) activity during dendritic-cell maturation. Blood (2005) 106:2375-81. doi:10.1182/blood-2005-03-0979

6. Beutelspacher SC, Tan PH, McClure MO, Larkin DF, Lechler RI, George AJ. Expression of indoleamine 2,3-dioxygenase (IDO) by endothelial cells: implications for the control of alloresponses. Am J Transplant (2006) 6:1320-30. doi:10.1111/j.1600-6143.2006.01324.x

7. Uyttenhove C, Pilotte L, Théate I, Stroobant V, Colau D, Parmentier N, et al. Evidence for a tumoral immune resistance mechanism based on tryptophan degradation by indoleamine 2,3-dioxygenase. Nat Med (2003) 9:1269-74. doi:10.1038/nm934

8. Wang D, Feng X, Lu L, Konkel JE, Zhang H, Chen Z, et al. A CD8 T cell/ indoleamine 2,3-dioxygenase axis is required for mesenchymal stem cell suppression of human systemic lupus erythematosus. Arthritis Rheumatol (2014) 66:2234-45. doi:10.1002/art.38674

9. Taylor MW, Feng GS. Relationship between interferon-gamma, indoleamine 2,3-dioxygenase, and tryptophan catabolism. FASEB J (1991) 5:2516-22.

10. Sedlmayr P, Blaschitz A, Wintersteiger R, Semlitsch M, Hammer A, MacKenzie CR, et al. Localization of indoleamine 2,3-dioxygenase in human female reproductive organs and the placenta. Mol Hum Reprod (2002) 8:385-91. doi:10.1093/molehr/8.4.385

11. Munn DH, Mellor AL. Indoleamine 2,3 dioxygenase and metabolic control of immune responses. Trends Immunol (2013) 34:137-43. doi:10.1016/j.it. 2012.10.001

12. Pallotta MT, Orabona C, Volpi C, Vacca C, Belladonna ML, Bianchi R, et al. Indoleamine 2,3-dioxygenase is a signaling protein in long-term tolerance by dendritic cells. Nat Immunol (2011) 12:870-8. doi:10.1038/ni.2077

13. Barth H, Raghuraman S. Persistent infectious diseases say - IDO. Role of indoleamine-2,3-dioxygenase in disease pathogenesis and implications for therapy. Crit Rev Microbiol (2014) 40:360-8. doi:10.3109/1040841X.2012. 742037

14. Baban B, Penberthy WT, Mozaffari MS. The potential role of indoleamine 2, 3 dioxygenase (IDO) as a predictive and therapeutic target for diabetes treatment: a mythical truth. EPMA J (2010) 1:46-55. doi:10.1007/s13167-010-0009-2

15. Zelante T, Fallarino F, Bistoni F, Puccetti P, Romani L. Indoleamine 2,3dioxygenase in infection: the paradox of an evasive strategy that benefits the host. Microbes Infect (2009) 11:133-41. doi:10.1016/j.micinf.2008.10.007

16. Fallarino F, Grohmann U, You S, McGrath BC, Cavener DR, Vacca C, et al. The combined effects of tryptophan starvation and tryptophan catabolites down-regulate $\mathrm{T}$ cell receptor zeta-chain and induce a regulatory phenotype in naive T cells. JImmunol (2006) 176:6752-61. doi:10.4049/ jimmunol.176.11.6752

17. Sharma MD, Baban B, Chandler P, Hou DY, Singh N, Yagita H, et al. Plasmacytoid dendritic cells from mouse tumor-draining lymph nodes directly activate mature Tregs via indoleamine 2,3-dioxygenase. J Clin Invest (2007) 117:2570-82. doi:10.1172/JCI31911

\section{SUPPLEMENTARY MATERIAL}

The Supplementary Material for this article can be found online at http://www.frontiersin.org/article/10.3389/fimmu.2017.01522/ full\#supplementary-material.

18. Teixeira MM, Theodoro RC, de Carvalho MJ, Fernandes L, Paes HC, Hahn RC et al. Phylogenetic analysis reveals a high level of speciation in the Paracoccidioides genus. Mol Phylogenet Evol (2009) 52:273-83. doi:10.1016/j. ympev.2009.04.005

19. De Castro LF, Ferreira MC, da Silva RM, Blotta MH, Longhi LN, Mamoni RL. Characterization of the immune response in human paracoccidioidomycosis. J Infect (2013) 67:470-85. doi:10.1016/j.jinf.2013.07.019

20. Mamoni RL, Blotta MH. Kinetics of cytokines and chemokines gene expression distinguishes Paracoccidioides brasiliensis infection from disease. Cytokine (2005) 32:20-9. doi:10.1016/j.cyto.2005.07.006

21. Benard G, Romano CC, Cacere CR, Juvenale M, Mendes-Giannini MJ, Duarte AJ. Imbalance of IL-2, IFN-gamma and IL-10 secretion in the immunosuppression associated with human paracoccidioidomycosis. Cytokine (2001) 13:248-52. doi:10.1006/cyto.2000.0824

22. Calich VL, Singer-Vermes LM, Siqueira AM, Burger E. Susceptibility and resistance of inbred mice to Paracoccidioides brasiliensis. Br JExp Pathol (1985) 66:585-94.

23. Calich VLG, Blotta MHSL. Pulmonary paracoccidioidomycosis. 1st ed. In: Fidel P, Huffnagle G, editors. Fungal Immunology, From an Organ Perspective. (Vol. 1), New York: Springer (2005). p. 201-28.

24. Cano LE, Singer-Vermes LM, Vaz CAC, Russo M, Calich VL. Pulmonary paracoccidioidomycosis in resistant and susceptible mice: relationship among progression of infection, bronchoalveolar cell activation, cellular immune response, and specific isotype patterns. Infect Immun (1995) 63:1777-83.

25. Felonato M, Pina A, de Araujo EF, Loures FV, Bazan SB, Feriotti C, et al. Anti-CD25 treatment depletes Treg cells and decreases disease severity in susceptible and resistant mice infected with Paracoccidioides brasiliensis. PLoS One (2012) 7:e51071. doi:10.1371/journal.pone.0051071

26. Pina A, Bernardino S, Calich VL. Alveolar macrophages from susceptible mice are more competent than those of resistant mice to control initial Paracoccidioides brasiliensis infection. J Leukoc Biol (2008) 83:1088-99. doi:10.1189/jlb.1107738

27. Feriotti C, Loures FV, Frank de Araújo E, da Costa TA, Calich VL. Mannosylrecognizing receptors induce an M1-like phenotype in macrophages of susceptible mice but an M2-like phenotype in mice resistant to a fungal infection. PLoS One (2013) 8:e54845. doi:10.1371/journal.pone.0054845

28. Araújo EF, Loures FV, Bazan SB, Feriotti C, Pina A, Schanoski AS, et al Indoleamine 2,3-dioxygenase controls fungal loads and immunity in paracoccidioidomicosis but is more important to susceptible than resistant hosts. PLoS Negl Trop Dis (2014) 8:e3330. doi:10.1371/journal.pntd.0003330

29. Calich VLG, da Costa TA, Felonato M, Arruda C, Bernardino S, Loures FV, et al. Innate immunity to Paracoccidioides brasiliensis infection. Mycopathologia (2008) 165:223-36. doi:10.1007/s11046-007-9048-1

30. Pina A, de Araujo EF, Felonato M, Loures FV, Feriotti C, Bernardino S, et al. Myeloid dendritic cells (DCs) of mice susceptible to paracoccidioidomycosis suppress $\mathrm{T}$ cell responses whereas myeloid and plasmacytoid DCs from resistant mice induce effector and regulatory T cells. Infect Immun (2013) 81:1064-77. doi:10.1128/IAI.00736-12

31. Felonato M, Pina A, Bernardino S, Loures FV, de Araujo EF, Calich VLG. CD28 exerts protective and detrimental effects in a pulmonary model of paracoccidioidomycosis. Infect Immun (2010) 78:4922-35. doi:10.1128/IAI. 00297-10

32. Singer-Vermes LM, Caldeira CB, Burger E, Calich VLG. Experimental murine paracoccidioidomycosis: relationship among dissemination of the infection, humoral and cellular responses. Clin Exp Immunol (1993) 94:75-9. doi:10.1111/j.1365-2249.1993.tb05980.x

33. Ding AH, Nathan CF, Stuehr DJ. Release of reactive nitrogen intermediates and reactive oxygen intermediates from mouse peritoneal macrophages. Comparison of activating cytokines and evidence for independent production. J Immunol (1988) 141:2407-12. 
34. Mannering SI, Morris JS, Jensen KP, Purcell AW, Honeyman MC, van Endert PM, et al. A sensitive method for detecting proliferation of rare autoantigen-specific human T cells. J Immunol Methods (2003) 283:173-83. doi:10.1016/j.jim.2003.09.004

35. Orabona C, Pallotta MT, Volpi C, Fallarino F, Vacca C, Bianchi R, et al. SOCS3 drives proteasomal degradation of indoleamine 2,3-dioxygenase (IDO) and antagonizes IDO-dependent tolerogenesis. Proc Natl Acad Sci U S A (2008) 105:20828-33. doi:10.1073/pnas.0810278105

36. Orabona C, Pallotta MT, Grohmann U. Different partners, opposite outcomes: a new perspective of the immunobiology of indoleamine 2,3-dioxygenase. Mol Med (2012) 18:834-42. doi:10.2119/molmed.2012.00029

37. Bonifazi P, Zelante T, D’Angelo C, De Luca A, Moretti S, Bozza S, et al. Balancing inflammation and tolerance in vivo through dendritic cells by the commensal Candida albicans. Mucosal Immunol (2009) 2:362-74. doi:10.1038/ mi.2009.17

38. Araújo EF, Medeiros DH, Galdino NA, Condino-Neto A, Calich VL, Loures FV. Tolerogenic plasmacytoid dendritic cells control Paracoccidioides brasiliensis infection by inducting regulatory $\mathrm{T}$ cells in an IDO-dependent manner. PLoS Pathog (2016) 12:e1006115. doi:10.1371/journal.ppat.1006115

39. Lob S, Konigsrainer A, Zieker D, Brucher BL, Rammensee HG, Opelz G, et al. IDO1 and IDO2 are expressed in human tumors: levo- but not dextro1-methyl tryptophan inhibits tryptophan catabolism. Cancer Immunol Immunother (2009) 58:153-7. doi:10.1007/s00262-008-0513-6

40. Metz R, Duhadaway JB, Kamasani U, Laury-Kleintop L, Muller AJ, Prendergast GC. Novel tryptophan catabolic enzyme IDO2 is the preferred biochemical target of the antitumor indoleamine 2,3-dioxygenase inhibitory compound D-1-methyl-tryptophan. Cancer Res (2007) 67:7082-7. doi:10.1158/0008-5472.CAN-07-1872

41. De Araújo EF, Feriotti C, Galdino NAL, Preite NW, Calich VLG, Loures FV. The IDO-AhR axis controls Th17/Treg immunity in a pulmonary model of fungal infection. Front Immunol (2017) 8:880. doi:10.3389/fimmu.2017.00880

42. Montagnoli C, Bozza S, Gaziano R, Zelante T, Bonifazi P, Moretti S, et al. Immunity and tolerance to Aspergillus fumigatus. Novartis Found Symp (2006) 279:66-77. doi:10.1002/9780470035399.ch6

43. Schmidt SV, Schultze JL. New insights into IDO biology in bacterial and viral infections. Front Immunol (2014) 5:384-93. doi:10.3389/fimmu.2014.00384

44. Zelante T, Iannitti RG, Fallarino F, Gargaro M, De Luca A, Moretti S, et al. Tryptophan feeding of the IDO1-AhR axis in host-microbial symbiosis. Front Immunol (2014) 5:640. doi:10.3389/fimmu.2014.00640

45. Cano LE, Kashino SS, Arruda C, André D, Xidieh CF, Singer-Vermes LM, et al. Protective role of gamma interferon in experimental pulmonary paracoccidioidomycosis. Infect Immun (1998) 66:800-6.

46. Mezrich JD, Fechner JH, Zhang X, Johnson BP, Burlingham WJ, Bradfield CA. An interaction between kynurenine and the aryl hydrocarbon receptor can generate regulatory T cells. J Immunol (2010) 185:3190-8. doi:10.4049/ jimmunol.0903670

47. Puccetti P, Grohmann U. IDO and regulatory T cells: a role for reverse signalling and non-canonical Nf- $\kappa$ B activation. Nat Rev Immunol (2007) 7:817-23. doi:10.1038/nri2163

48. Fallarino F, Vacca C, Orabona C, Belladonna ML, Bianchi R, Marshall B, et al. Functional expression of indoleamine 2,3-dioxygenase by murine CD8a+ dendritic cells. Int Immunol (2002) 14:1206-12. doi:10.1093/intimm/14.1.65

49. Grohmann U, Fallarino F, Bianchi R, Belladonna ML, Vacca C, Orabona C, et al. IL- 6 inhibits the tolerogenic function of CD8 $\alpha+$ dendritic cells expressing indoleamine 2,3-dioxygenase. J Immunol (2001) 167:708-14. doi:10.4049/ jimmunol.167.2.708
50. Romani L. Immunity to fungal infections. Nat Rev Immunol (2011) 11:275-88. doi:10.1038/nri2939

51. Loures FV, Pina A, Felonato M, Araújo EF, Leite KR, Calich VL. Toll-like receptor 4 signaling leads to severe fungal infection associated with enhanced proinflammatory immunity and impaired expansion of regulatory $\mathrm{T}$ cells. Infect Immun (2010) 78:1078-88. doi:10.1128/IAI.01198-09

52. Read AF, Graham AL, Raberg L. Animal defenses against infectious agents: is damage control more important than pathogen control. PLoS Biol (2008) 6:e4. doi:10.1371/journal.pbio.1000004

53. Schneider DS, Ayres JS. Two ways to survive infection: what resistance and tolerance can teach us about treating infectious diseases. Nat Rev Immunol (2008) 8:889-95. doi:10.1038/nri2432

54. Bessede A, Gargaro M, Pallotta MT, Matino D, Servillo G, Brunacci C, et al. Aryl hydrocarbon receptor control of a disease tolerance defence pathway. Nature (2014) 511:184-90. doi:10.1038/nature13323

55. Romani L, Zelante T, De Luca A, Iannitti RG, Moretti S, Bartoli A, et al. Microbiota control of a tryptophan-AhR pathway in disease tolerance to fungi. Eur J Immunol (2014) 44:3192-200. doi:10.1002/eji.201344406

56. Nguyen NT, Kimura A, Nakahama T, Chinen I, Masuda K, Nohara K, et al. Aryl hydrocarbon receptor negatively regulates dendritic cell immunogenicity via a kynurenine-dependent mechanism. Proc Natl Acad Sci U S A (2010) 107:19961-6. doi:10.1073/pnas.1014465107

57. Benard G, Costa AN, Ravanini J, Goulart S, Nicodemo EL, Barbas CS, et al. Fatal acute respiratory distress syndrome in a patient with paracoccidioidomycosis: first case report. Med Mycol (2010) 48:542-5. doi:10.3109/ 13693780903330563

58. Gryschek RC, Pereira RM, Kono A, Patzina RA, Tresoldi AT, ShikanaiYasuda MA, et al. Paradoxical reaction to treatment in 2 patients with severe acute paracoccidioidomycosis: a previously unreported complication and its management with corticosteroids. Clin Infect Dis (2010) 50:e56-8. doi:10.1086/652290

59. Arruda C, Kashino SS, Fazioli RA, Calich VL. A primary subcutaneous infection with Paracoccidioides brasiliensis leads to immunoprotection or exacerbated disease depending on the route of challenge. Microbes Infect (2007) 9:308-16. doi:10.1016/j.micinf.2006.12.005

60. Arruda C, Vaz CA, Calich VL. Aseptic cure of pulmonary paracoccidioidomycosis can be achieved after a previous subcutaneous immunization of susceptible but not resistant mice. Microbes Infect (2007) 9:704-13. doi:10.1016/ j.micinf.2007.02.014

61. Mondanelli G, Bianchi R, Pallotta MT, Orabona C, Albini E, Iacono A, et al. A relay pathway between arginine and tryptophan metabolism confers immunosuppressive properties on dendritic cells. Immunity (2017) 46:233-44. doi:10.1016/j.immuni.2017.01.005

Conflict of Interest Statement: The authors declare that the research was conducted in the absence of any commercial or financial relationships that could be construed as a potential conflict of interest.

Copyright (c) 2017 de Araújo, Loures, Feriotti, Costa, Vacca, Puccetti, Romani and Calich. This is an open-access article distributed under the terms of the Creative Commons Attribution License (CC BY). The use, distribution or reproduction in other forums is permitted, provided the original author(s) or licensor are credited and that the original publication in this journal is cited, in accordance with accepted academic practice. No use, distribution or reproduction is permitted which does not comply with these terms. 